\title{
Certain Caddo Sites in the Ouachita Mountains of Southwestern Arkansas
}

Timothy K. Perttula

Heritage Research Center, Stephen F. Austin State University

Bo Nelson

Heritage Research Center, Stephen F. Austin State University

Follow this and additional works at: https://scholarworks.sfasu.edu/ita

Part of the American Material Culture Commons, Archaeological Anthropology Commons, Environmental Studies Commons, Other American Studies Commons, Other Arts and Humanities Commons, Other History of Art, Architecture, and Archaeology Commons, and the United States History Commons

Tell us how this article helped you.

This Article is brought to you for free and open access by the Center for Regional Heritage Research at SFA ScholarWorks. It has been accepted for inclusion in Index of Texas Archaeology: Open Access Gray Literature from the Lone Star State by an authorized editor of SFA ScholarWorks. For more information, please contact cdsscholarworks@sfasu.edu. 


\section{Certain Caddo Sites in the Ouachita Mountains of Southwestern Arkansas}

Creative Commons License

(c) (i) (8)

This work is licensed under a Creative Commons Attribution-NonCommercial 4.0 International License 


\section{Certain Caddo Sites in the Ouachita Mountains}

\section{of Southwestern Arkansas}

Timothy K. Perttula and Bo Nelson

\section{Introduction}

In the last few years, we have had the opportunity to study a number of prehistoric Caddo Indian sites in the Ouachita Mountains of southwestern Arkansas through conducting archeological surveys of more than 2700 acres at three lakes constructed and managed by the U.S. Army Corps of Engineers, Vicksburg District (Perttula and Nelson 2000, 2001, 2002). The three lakes are DeGray Lake on the Caddo River, Lake Ouachita on the Ouachita River, and Lake Greeson on the Little Missouri River (Figure 1).

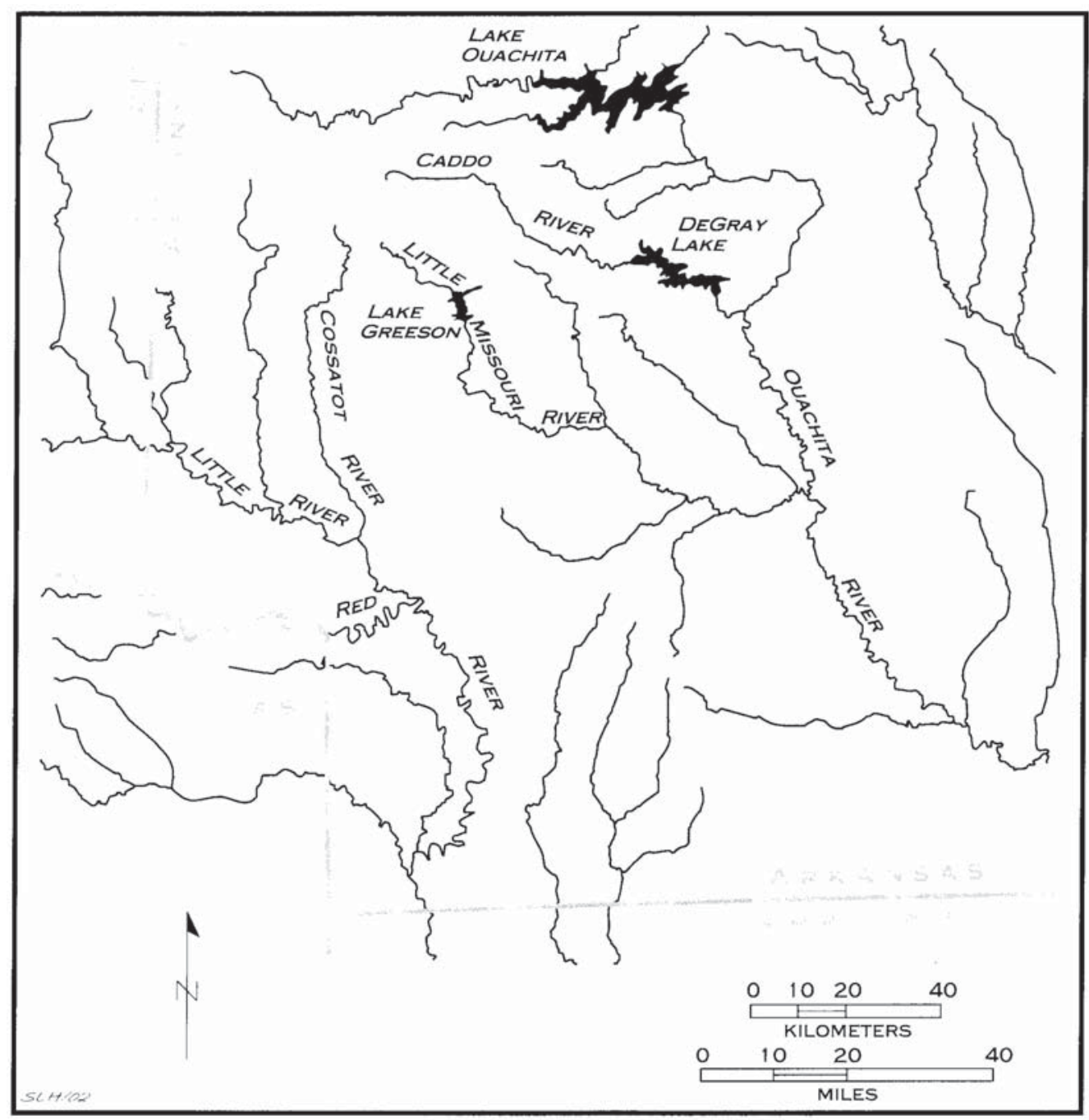

Figure 1. Locations of Lake Greeson, Lake Ouachita, and DeGray Lake in southwestern Arkansas. 
Our purpose in this article is to summarize the archeological character of the prehistoric Caddo sites in these three different parts of the Ouachita Mountains. We focus in particular on the material culture record of these prehistoric Caddo settlements-especially on the ceramic sherds found on them-and discuss when these sites may have been occupied by Caddo peoples.

\section{Caddo Sites at DeGray Lake, Clark County}

\section{Cox Creek Site (3CL739)}

The Cox Creek site is an extremely large $\left(120,000 \mathrm{~m}^{2}\right)$ prehistoric archeological deposit on an alluvial terrace and gently sloping ridge (410-430 feet amsl) at the confluence of Cox Creek and the Caddo River. The density of prehistoric artifacts here (63.6 artifacts per positive shovel test, or about 600 artifacts per $\mathrm{m}^{2}$ ) far surpasses any of the other prehistoric sites at DeGray Lake.

The old channel of the Caddo River is about $25 \mathrm{~m}$ from the edge of the terrace and ridge landform, and it forms a large meander as it passes the site. This prehistoric site is in an abandoned recreational area, and has been disturbed by road construction and other park development activities, as well as looting (see below). The site is wooded, with generally poor visibility; around the looter holes, visibility is somewhat better because of the exposures created by the digging activities.

Mr. Wayne Stogsdill of the Vicksburg District pointed out one area within the site that has been looted in the last several years. The looter holes are concentrated in a $70 \times 40 \mathrm{~m}$ area of a Vicksburg District camping area covered with hardwoods and scattered pines. The area appears to have been previously terraced for agricultural purposes. This looting is in a prehistoric Early to Middle Caddoan midden area (Figure 2), and the looting has apparently been ongoing for some time; old and new holes sometimes have been either left open or covered up to avoid detection, but the looting activities are obvious and substantial. Looting activities occurred while our archeological survey investigations were on-going.

More than 30 looter holes of various sizes were documented in this one area (Figure 3). The dimensions and depths of the looter holes were measured (Table 1), and the looter holes were mapped; any diagnostic prehistoric artifacts (i.e., projectile points or prehistoric ceramics) noted in the backdirt piles were collected as part of our investigations.

At least $76 \mathrm{~m}^{2}$ of the midden appears to have been recently looted; there are older looter holes in the midden area that could not be accurately mapped. This comprises at least $8.5 \%$ of the midden's surface area. The recent looting has disturbed and/or removed approximately $21 \mathrm{~m}^{3}$ (see Table 1).

Shovel testing was initiated in the looter hole area, and continued across the landform; a total of 75 shovel tests were excavated at the Cox Creek site, and 61 contained prehistoric archeological materials. The Pirum-Sherless-Shermore sediments range from 5-60 cm in thickness here, with the thinner deposits generally restricted to the ridge landform and the higher elevations.

There is a prehistoric midden deposit in the looted part of the site that is an estimated $45 \mathrm{x}$ $20 \mathrm{~m}$ in size (see Figure 2); it is a maximum of $40 \mathrm{~cm}$ in thickness in ST 562 . The upper $26 \mathrm{~cm}$ of the midden is a dark brown sandy loam, while the lower midden (ca. 26-40 cm bs) is a very dark brown sandy loam with charcoal flecks, fire-cracked rocks, and an area of oxidized soil that may be a hearth feature. Both the upper and lower midden samples contain an abundance of prehistoric Caddo pottery sherds in the shovel testing $(n=18)$, occurring at a density of ca. 200 sherds per $\mathrm{m}^{2}$. The midden formed in a yellowish-brown sandy loam of the Pirum-Sherless-Shermore soil; the total thickness of the A-horizon sediments is ca. $50 \mathrm{~cm}$. These rest on a yellowish-red clayey loam B-horizon. 


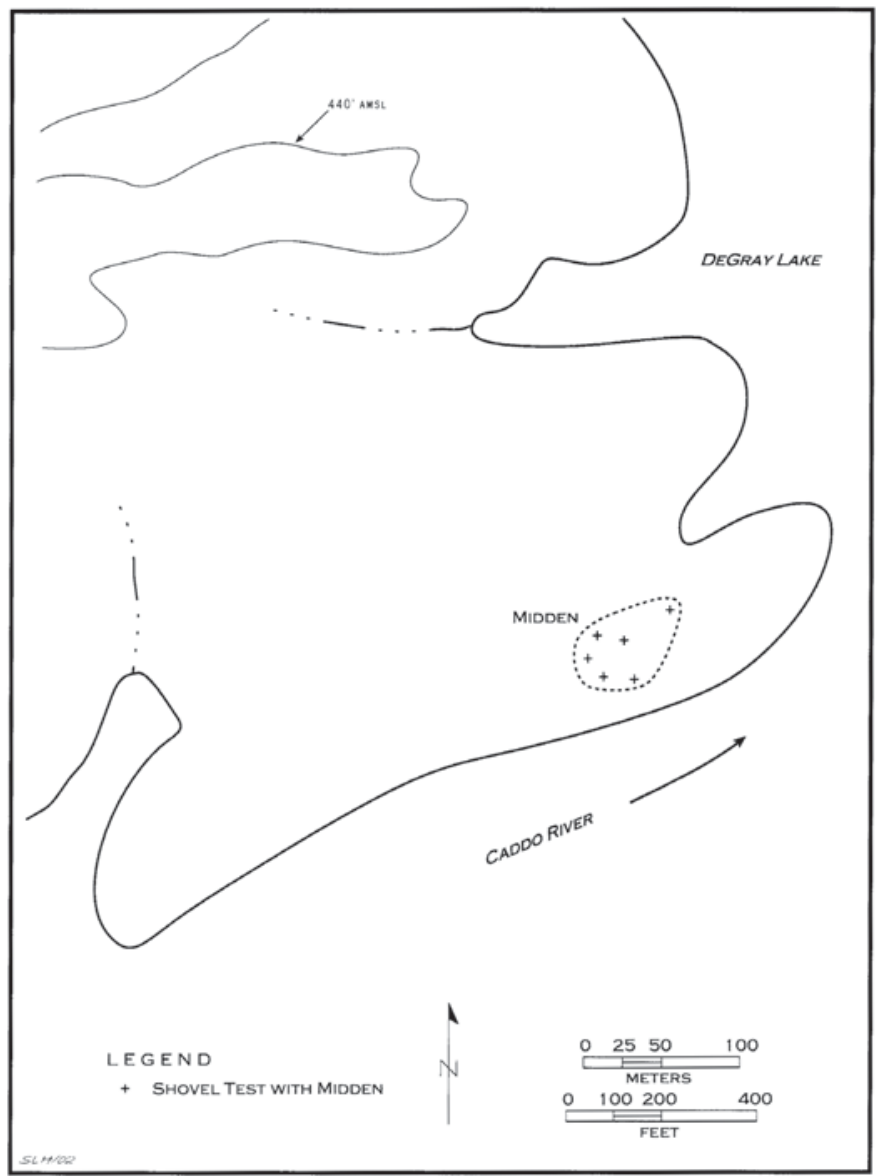

Figure 2. Location of the midden at the Cox Creek site (3CL739)

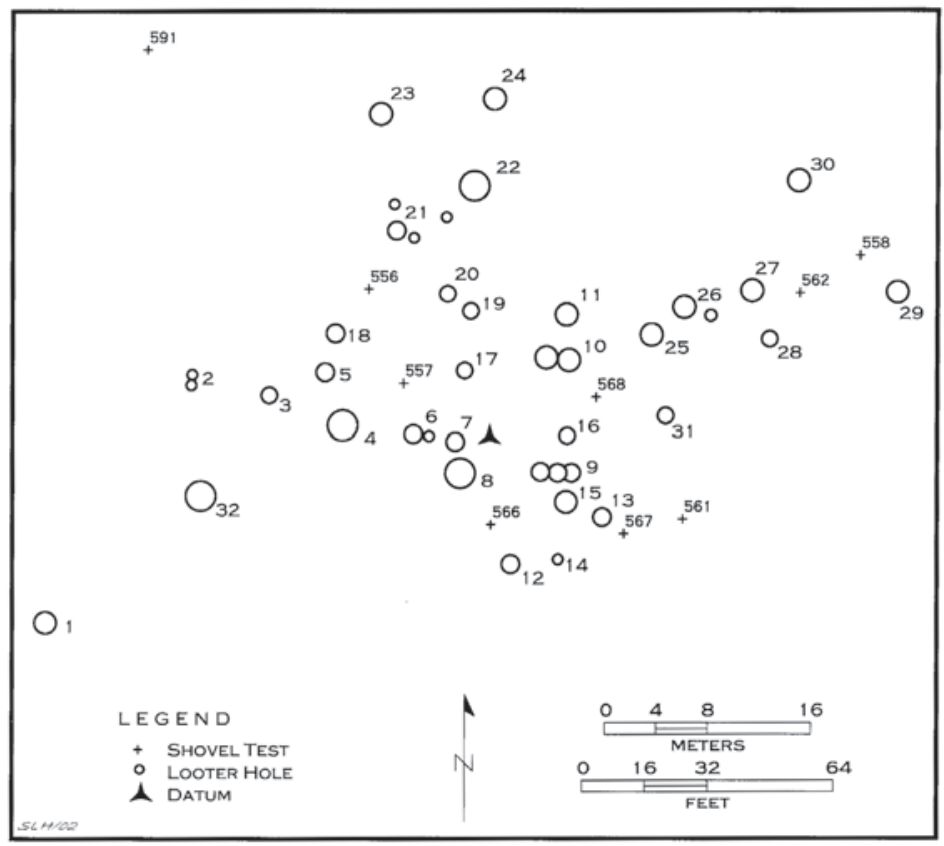

Figure 3. Looted areas and shovel tests at the Cox Creek site midden. 
An area of oxidized soil, charcoal flecking, and fire-cracked sandstone (eight pieces weighing $1.4 \mathrm{~kg}$ ) was exposed in ST 562 (see Figure 3) between ca. 28-44 cm bs in the lower midden deposit; there were also two chert cobbles and a ceramic sherd found in apparent association. The probable hearth feature covered the northern half of the shovel test, and is at least an estimated $30-50 \mathrm{~cm}$ in length and width.

Sediment samples (ca. 200 g) from ST 562 were submitted for Oxidizable Carbon Ratio (OCR) dating from an area with an abundance of Caddo pottery sherds. Frink (1992, 1994, 1995, 1999) and Frink and Perttula (2001) discuss the OCR dating method and procedures in detail. Sediment samples were taken at $5 \mathrm{~cm}$ intervals, beginning at $5 \mathrm{~cm} \mathrm{bs}$, and extending to $55 \mathrm{~cm}$ bs. The first eight samples are in the prehistoric midden deposit with abundant lithic and ceramic artifacts, charcoal flecks, and fire-cracked rocks; as previously mentioned, there is a concentration of oxidized soil between $28-44 \mathrm{~cm}$ bs. The results of the OCR dating procedure are presented in Table 2 (see also Perttula and Nelson 2000: Appendix V).

Table 1. Dimensions and depths of the recent looter holes in the midden deposits at the Cox Creek site (3CL739).

\begin{tabular}{|c|c|c|}
\hline Looter Hole \# & Length and Width (in m) & Depth (in cm) \\
\hline 1 & $0.75 \times 0.75$ & 35 \\
\hline 2 & $0.50 \times 0.50$ & 40 \\
\hline 3 & $1 \times 0.50$ & 35 \\
\hline 4 & $2 \times 2$ & 20 \\
\hline 5 & $0.75 \times 0.75$ & 20 \\
\hline 6 & $1 \times 1,0.50 \times 0.50$ & 25 \\
\hline 7 & $1 \times 1.5$ & 25 \\
\hline 8 & $3 \times 3$ & 30 \\
\hline 9 & $1 \times 4$ & 30 \\
\hline 10 & $4 \times 4$ & 20 \\
\hline 11 & $1.5 \times 1.5$ & 40 \\
\hline 12 & $1 \times 0.50$ & 30 \\
\hline 13 & $1 \times 0.50$ & 45 \\
\hline 14 & $0.50 \times 0.50$ & 30 \\
\hline 15 & $1 \times 1$ & 30 \\
\hline 16 & $1 \times 0.50$ & 30 \\
\hline 17 & $1 \times 1$ & 30 \\
\hline 18 & $1 \times 0.50$ & 20 \\
\hline 19 & $0.50 \times 0.50$ & 20 \\
\hline 20 & $0.75 \times 0.75$ & 30 \\
\hline 21 & $1 \times 1,0.50 \times 0.50$ & 40 \\
\hline 22 & $2 \times 2,0.50 \times 0.50$ & 45 \\
\hline 23 & $1.5 \times 1$ & 40 \\
\hline 24 & $1 \times 1$ & 50 \\
\hline 25 & $2 \times 2$ & 20 \\
\hline 26 & $1 \times 1$ & 20 \\
\hline 27 & $2 \times 2$ & 20 \\
\hline 28 & $1 \times 1$ & 50 \\
\hline 29 & $1 \times 0.50$ & 35 \\
\hline 30 & $2 \times 2$ & 20 \\
\hline 31 & $1 \times 1$ & 20 \\
\hline 32 & $3 \times 3$ & 32 \\
\hline
\end{tabular}


Table 2. Oxidizable Carbon Ratio dates from the Cox Creek site (3CL739).

Laboratory Sample No. $\quad$ Depth below surface Calculated OCR Dates

\begin{tabular}{llr}
\hline & \multicolumn{2}{c}{ Upper Midden } \\
ACT 4525 & $5 \mathrm{~cm}$ & $440 \pm 13 \mathrm{BP}, \mathrm{AD} 1493-1519$ \\
ACT 4527 & $10 \mathrm{~cm}$ & $514 \pm 15 \mathrm{BP}, \mathrm{AD} 1421-1451$ \\
ACT 4528 & $15 \mathrm{~cm}$ & $507 \pm 15 \mathrm{BP}, \mathrm{AD}$ 1428-1458 \\
ACT 4529 & $20 \mathrm{~cm}$ & $560 \pm 16 \mathrm{BP}, \mathrm{AD} 1374-1406$ \\
ACT 4530 & $25 \mathrm{~cm}$ & $531 \pm 15 \mathrm{BP}, \mathrm{AD} 1404-1434$
\end{tabular}

\section{Lower Midden}

$\begin{array}{lll}\text { ACT } 4531 & 30 \mathrm{~cm} & 616 \pm 18 \text { BP, AD 1316-1352 } \\ \text { ACT 4521 } & 35 \mathrm{~cm} & 734 \pm 22 \text { BP, AD 1194-1238 } \\ \text { ACT 4522 } & 40 \mathrm{~cm} & 870 \pm 26 \text { BP, AD 1054-1106 }\end{array}$

\section{Sandy Loam Deposits Under Midden}

ACT 4523

$45 \mathrm{~cm}$

$1476 \pm 44 \mathrm{BP}, \mathrm{AD} 430-518$

ACT 4524

$50 \mathrm{~cm}$

$1743 \pm 52 \mathrm{BP}, \mathrm{AD} 155-259$

\section{Clayey Loam B-Horizon}
ACT 4526
$55 \mathrm{~cm}$
$3444 \pm 103$
B P, BC $1597-$ 1391

Based on differences in soil $\mathrm{pH}$, elevated frequencies of coarse and very coarse particles in the sediment column through the midden (see Perttula and Nelson 2000: Appendix V), and the depth and character of the midden deposits, Frink (2000 personal communication) suggested that the cultural age of the upper midden deposits range between ca. 514-560 BP, or ca. A.D. 13901436. The lower midden deposit's age is best represented by the OCR sample at $40 \mathrm{~cm}$ bs, or about A.D. 1054-1106. These dates together indicate that the prehistoric Caddo midden built up over a period of approximately 300 to 400 years. Finally, very elevated frequencies of coarse particles in sample ACT 4524 (see Table 2) at $50 \mathrm{~cm}$ bs, followed by elevated fine particles in the overlying sample, suggests that there was an early cultural occupation at the site around A.D. 200, during the Woodland period.

The prehistoric archeological remains at the Cox Creek site, in addition to the one midden deposit, are concentrated on the terrace paralleling the Caddo River. Lithic debris-primarily novaculite-is found in virtually every shovel test, and in great quantities. The only three cores, however, are restricted to the southwestern part of the site ( 420 feet amsl), in one of the two areas with the highest densities (more than 70 pieces of lithic debris per shovel test) of lithic debris, labeled Area B on Figure 4. These areas are about $75 \mathrm{~m}$ apart; Area A is about 220 x $100 \mathrm{~m}$ in size, and Area B is $150 \times 50 \mathrm{~m}$. These areas have more than $80 \%$ of the lithic debris found on the Cox Creek site.

Both areas contain similar kinds of lithic raw materials represented among the lithic debris (Table 3), including large amounts of white novaculite, gray novaculite, pink novaculite, orange and red novaculite, local cherts, and Big Fork chert. There are no significant differences in the 
proportions of the raw material in the debris, suggesting that similar sources were used for the procurement of raw materials during the different prehistoric occupations at the site.

Table 3. Lithic raw materials in Area A and B lithic debris, Cox Creek site (3CL739).

\begin{tabular}{lll}
\hline & Area A & Area B \\
Raw Material & & \\
\hline white novaculite & $52.4 \%$ & $55.3 \%$ \\
gray novaculite & $16.4 \%$ & $17.6 \%$ \\
pink novaculite & $9.7 \%$ & $8.9 \%$ \\
orange novaculite & $4.7 \%$ & $4.4 \%$ \\
red novaculite & $4.1 \%$ & $2.8 \%$ \\
yellow novaculite & $1.0 \%$ & $0.4 \%$ \\
white-black novaculite & $0.9 \%$ & $0.5 \%$ \\
gray-black novaculite & $0.9 \%$ & $0.4 \%$ \\
black novaculite & $0.7 \%$ & $1.1 \%$ \\
brown novaculite & $0.4 \%$ & $0.3 \%$ \\
white-gray novaculite & $0.1 \%$ & $0.4 \%$ \\
gray-yellow novaculite & trace & $0.1 \%$ \\
red-brown novaculite & trace & $0.0 \%$ \\
red-black novaculite & & $0.0 \%$ \\
Big Fork chert & $2.3 \%$ & $2.8 \%$ \\
local cherts & $5.3 \%$ & $3.9 \%$ \\
quartz & $1.0 \%$ & $1.0 \%$ \\
quartzite & trace & $0.0 \%$ \\
siliceous shale & trace & $0.0 \%$ \\
\hline
\end{tabular}

Fire-cracked rocks are also concentrated in areas A and B, but with very little areal separation between them across the terrace; one shovel test on the ridge also has a bit of fire-cracked rock. The densest amounts of fire-cracked rock are found primarily in Area A shovel tests (Figure 5).

A wide assortment of prehistoric tools are found broadly dispersed across the Cox Creek site, but as with the other classes of artifacts, the tools tend to concentrate in areas A and B (Figure $6)$. Tools include dart points, arrow points $(n=3)$ and arrow point preforms $(n=1)$, bifacial tool fragments, bifaces, groundstone tools, and various flake and scraping (end and side scrapers) tools. All the groundstone tools (five mano and mano fragments and one grinding slab fragment of Jackfork sandstone) are concentrated in the Area A midden. The temporally diagnostic artifacts include a Middle Archaic Johnson point, Woodland or Fourche Maline Gary, var. Camden $(\mathrm{n}=2)$ points, and an Early to Middle Caddo unidentified arrow tip, respectively, from Area A, along with an expanding stem side-notched dart point, possibly of the Late Archaic Mena side-notched type. In Area $\mathrm{B}$, there is an orange novaculite Dalton point of Late Paleoindian age, a Late Archaic Williams point, one Gary, var. Camden, and two corner-notched arrow points, including one that resembles an Agee (Figure 7d). The only temporally diagnostic lithic tool on the ridge landform is an arrow point preform in ST 585 (see Figure 6).

One of the arrow points at the Cox Creek site has an expanding stem with corner-notching and a flat to slightly convex base (see Figure 7e). The blade is not serrated. It resembles Early to Middle Caddoan period arrow points, probably the Scallorn B form defined by Brown (1996:442 and Figure 2-61f-h). Another from the site may be an Agee (see Figure 7d). It has a convex base, 


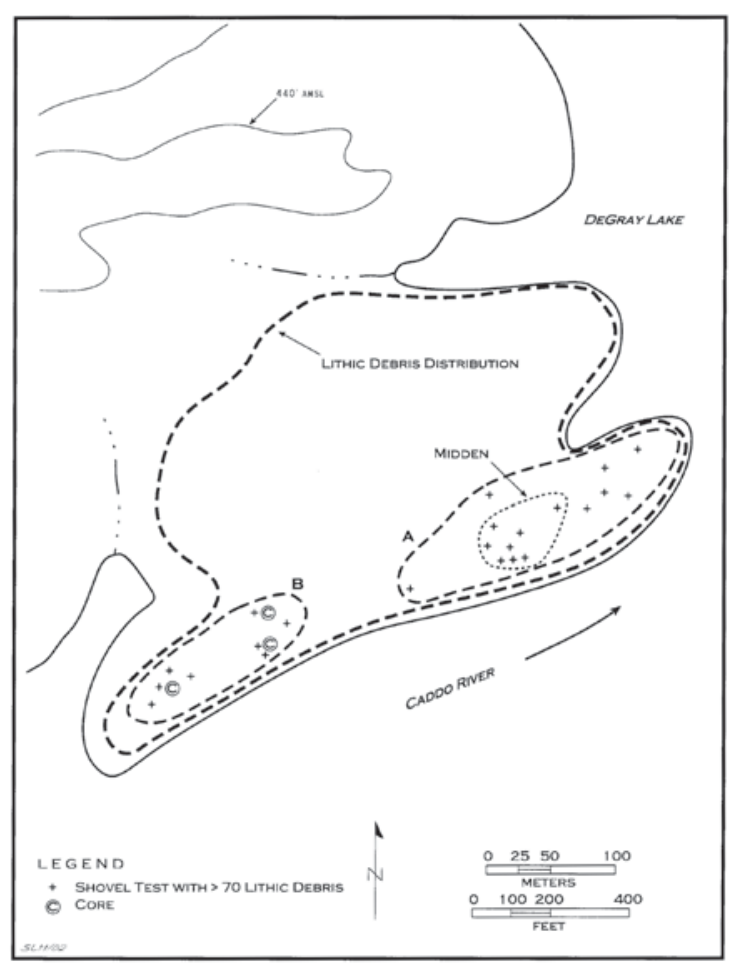

Figure 4. Distribution of cores and lithic debris at the Cox Creek site.

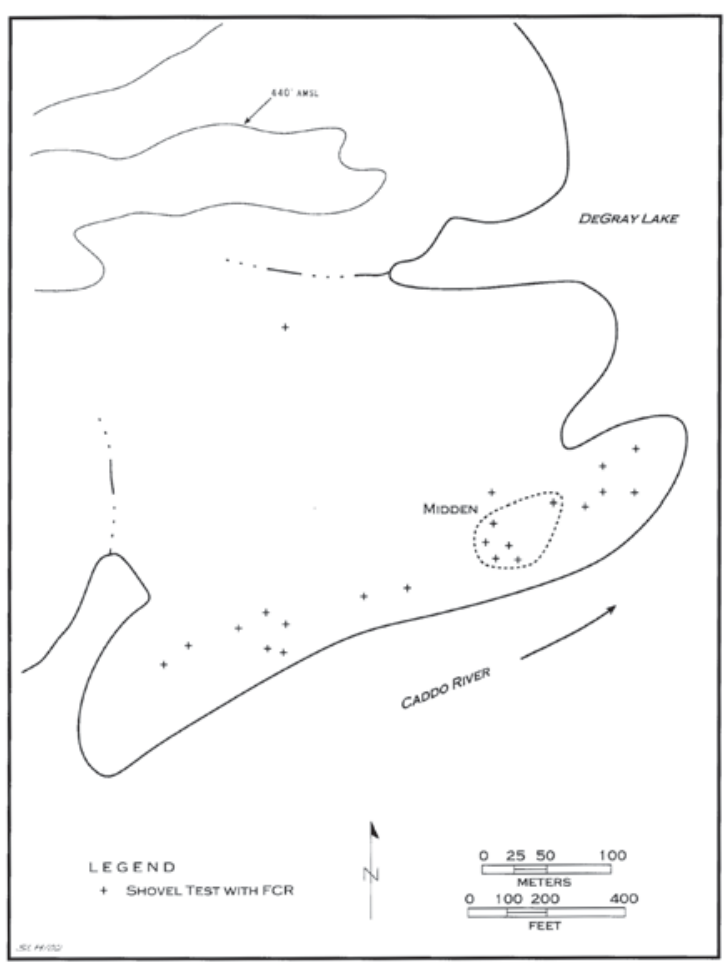

Figure 5. Shovel tests at the Cox Creek site with firecracked rock.

a slightly recurved blade, small barbs, and relatively deep corner notches. Schambach (1982) has suggested that the Agee arrow points at the Crenshaw site along the Red River date to the latter part of the Woodland period, and Early (1988:105) and Brown (1996) also consider Agee points to have been made in early Caddoan times, perhaps before A.D. 1050. The arrow point preform from the site is an ovoid and bifacially-worked piece of white novaculite that is only $2.8 \mathrm{~mm}$ thick and $18.8 \mathrm{~mm}$ in width.

Prehistoric ceramics are found in shovel testing and looter hole backdirt only on the terrace landform, but again they occur in two clusters (Figure 8). These correspond to Areas A and B already identified from the prehistoric lithic debris, fire-cracked rock, and chipped stone tools. The ceramics are particularly common in Area A midden contexts, and 19 of the looter hole backdirt piles had sherds exposed on them. The Area A ceramic cluster is ca. 120 x $80 \mathrm{~m}$ in size, compared to 50 x $50 \mathrm{~m}$ in size for Area B. The only piece of daub from the Cox Creek site is from Area A.

The Area A ceramic cluster contains Early to Middle Caddo plain and decorated sherds, including Military Road Incised and Friendship Engraved, and the few Late Caddoan shell-tempered sherds also occur in the Area A midden. The only decorated sherds in Area B are two grog-gritbone-tempered pieces with broad incised lines and a fingernail punctated sherd with bone temper (Figure 9).

Bone-tempered, grit-bone-tempered, and grog-grit-bone-tempered sherds are found in both ceramic clusters, but none in large amounts. Grit-tempered sherds, probably the Woodland or Fourche Maline Ouachita Ironware, var. Catherine, are almost exclusively found in Area A looter holes and shovel testing. These sherds are found in low numbers throughout the midden deposit-with one sherd from a context immediately below the midden-indicating the midden was probably developed atop earlier Woodland (and Archaic) occupational debris along this part of the terrace.

The Cox Creek site has 158 sherds and one piece of daub. Included in the sherds are four 


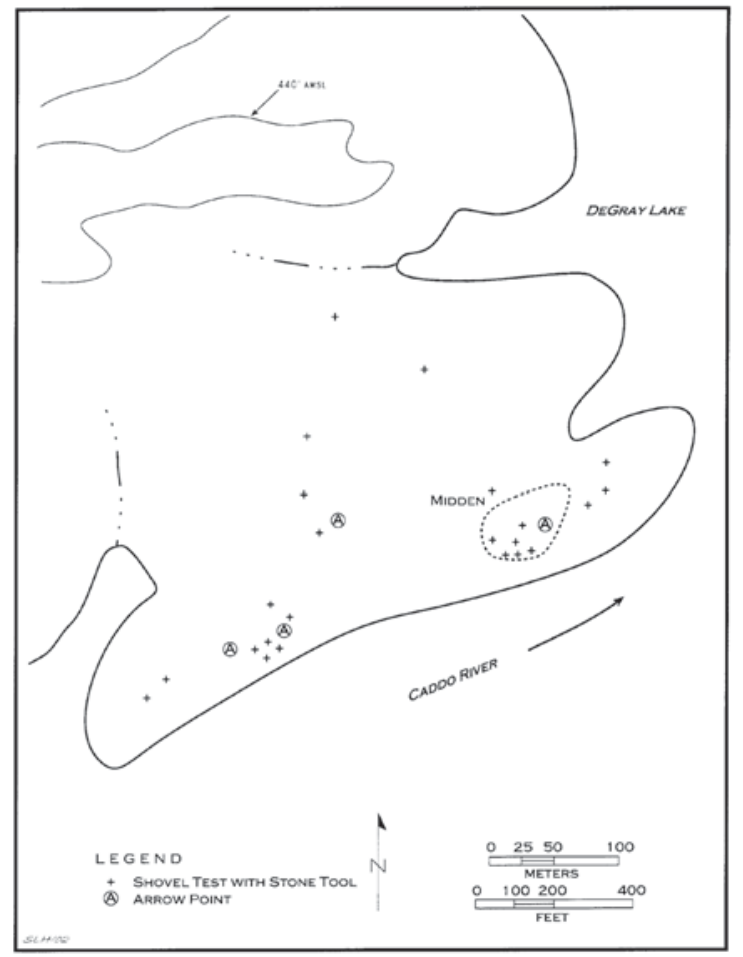

Figure 6. Distribution of stone tools and arrow points at the Cox Creek site. rims, three bases, 129 body sherds, and 22 sherdlets. Seventeen sherds, including one rim, have decorations, representing $10.8 \%$ of the assemblage, and $12.5 \%$ of the non-sherdlets. One of the bases, tempered with grog and grit, has basketry impressions on its exterior surface.

Grog-tempered sherds are most common at the Cox Creek site, representing $41 \%$ of the sample, followed by grit-tempered, sandy paste sherds $(21.9 \%)$. The total percentage of sherds with grog (crushed sherd temper) in the assemblage, irrespective of its occurrence with other temper combinations, is $69 \%$.

The grog-tempered sherds are moderately thick (mean=6.75 $\pm 1.06 \mathrm{~mm}$ ), with high proportions of sherds from vessels that were either incompletely oxidized during firing or reduced during firing, but cooled in a high oxygen environment (see Perttula and Nelson 2000: Table 25). The grog-tempered sherds may be from Williams Plain vessels, and various Caddo decorated vessels, because they are no slipped or burnished (Poole Plain) grog-tempered sherds in the assemblage.

The grit-tempered sherds have a sandy paste and are tempered with crushed rock, typically novaculite, but there are also pieces of crushed quartz in the paste. These sherds appear to be Ouachita Ironware, probably var. Catherine, rather than LeFlore Plain, because they are not smoothed or burnished (see Early 1988; Schambach 1998). They have thin vessel walls (5.73 $\pm 0.86 \mathrm{~mm})$, and are from vessels that usually have been fired in a reducing environment. More than $82 \%$ of the grit-tempered sherds have been fired under those conditions. Two grit-tempered sherds have

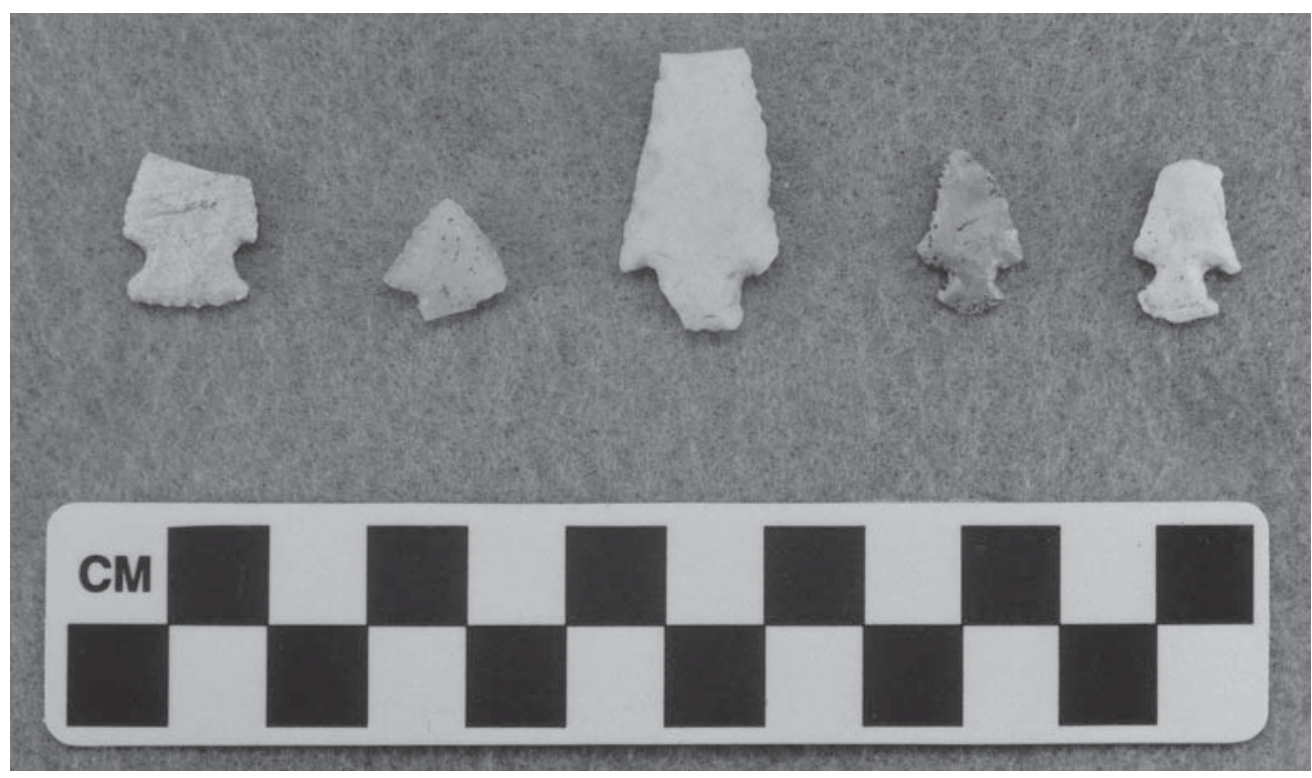

Figure 7. Arrow points from DeGray Lake Caddo sites: a, Hatchet site (3HS544); b, Point Cedar South Camp (3CL759); c; Lambert (3HS458); d-e, Cox Creek (3CL739). 


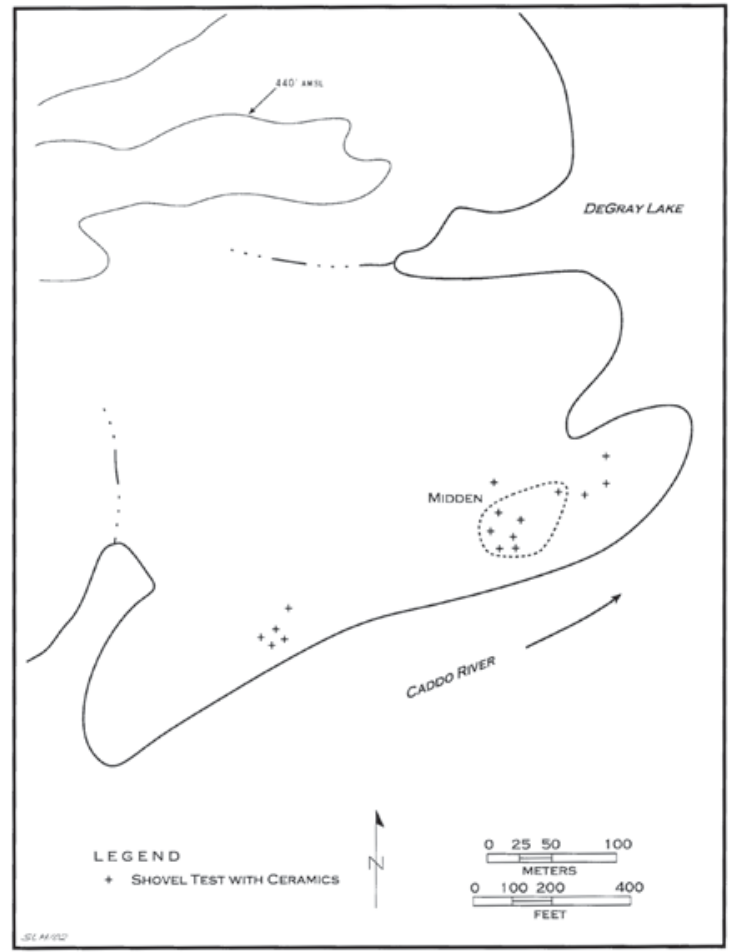

Figure 8. Distribution of ceramic sherds at the Cox Creek site. incised or punctated decorations (see below).

The shell-tempered sherds are from Late Caddoan cooking jars of the Woodward Plain type. They are very thin $(5.26 \pm 0.61 \mathrm{~mm})$, and principally fired in a reducing environment. Two shell-tempered sherds have Class $\mathrm{C}$ punctated decorations.

Grog-grit-tempered Williams Plain sherds account for $15.6 \%$ of the analyzed sherds. They are relatively thick on average $(7.12 \pm 0.88 \mathrm{~mm})$, and were principally fired in a reducing environment, but cooled in a high oxygen environment. One grog-grittempered sherd has an incised decoration. There are also nine sherds $(7 \%)$ of Williams Plain that have a grog temper and a sandy paste. They have slightly thinner vessel walls $(6.49 \pm 1.05 \mathrm{~mm})$, but again are from vessels that were fired in a reducing environment, but cooled in a high oxygen environment. One of these sherds also has an incised decoration.

The only other temper combinations represented in the sherds together comprise only $8.6 \%$ of the sherds, and include grit-bone ( $\mathrm{n}=2)$, grog-grit-bone $(n=4)$, bone $(n=3)$, and grog-bone $(n=2)$. The grit-

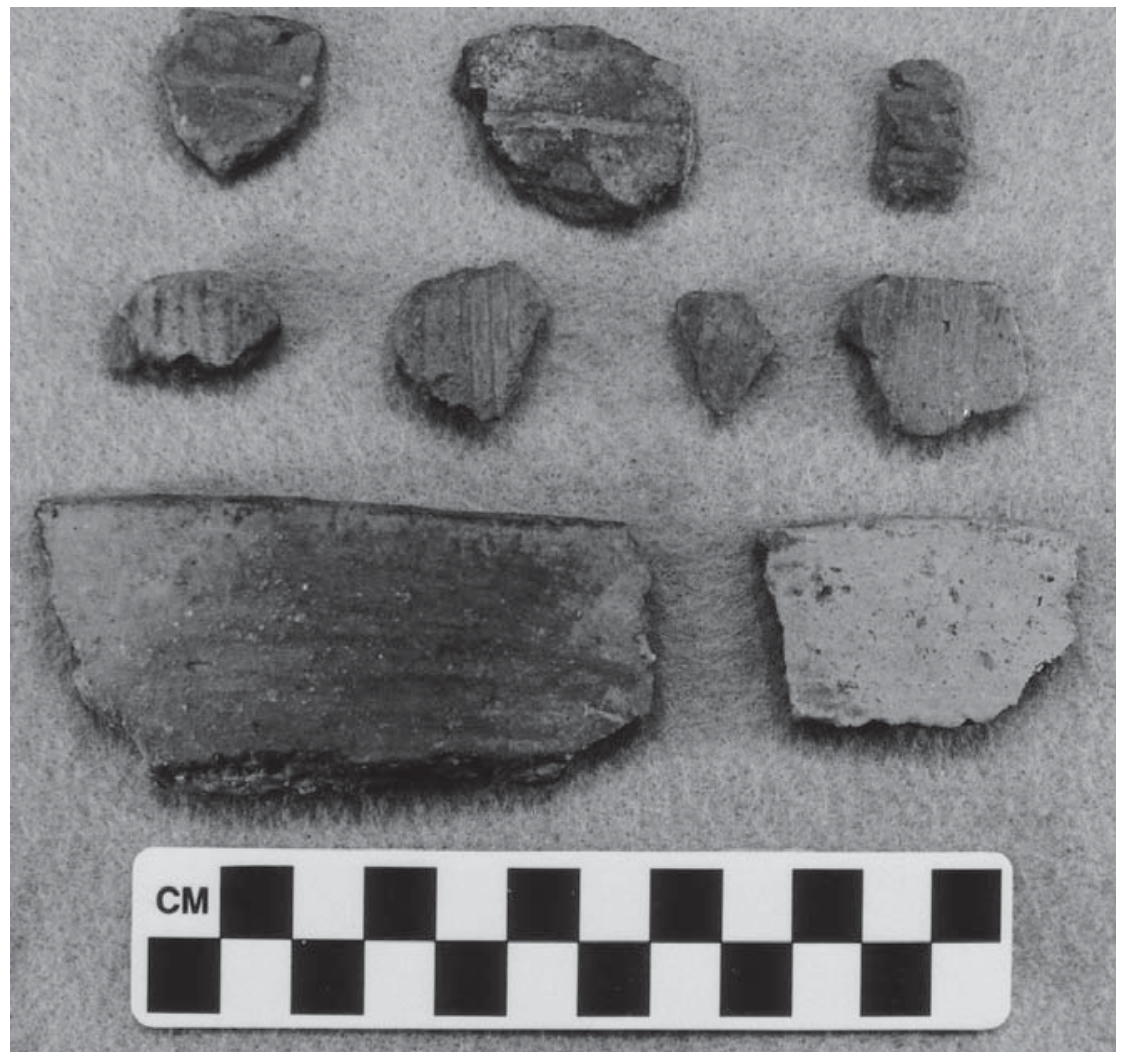

Figure 9. Prehistoric ceramics from DeGray Lake Caddo sites: a, c-i, Cox Creek (3CL739); b, Crow Road (3CL749). 
bone-tempered sherds are thin $(6.15 \mathrm{~mm} \pm 0.25 \mathrm{~mm})$, while the others have thicker vessel walls (ranging from 7.10-7.20 $\mathrm{mm}$ on average). The grit-bone-tempered and grog-grit-bone-tempered sherds are from vessels that were reduced during firing, as with much of the assemblage from the site (see Perttula and Nelson 2000: Table 25), while the bone and grog-bone-tempered sherds were primarily from vessels that were incompletely oxidized during firing. As previously discussed, the highest proportions of incompletely oxidized sherds occur in the grog-tempered wares.

Those few sherds with bone are not Cooper Boneware (see Schambach 1998) from Fourche Maline contexts, as the bone temper particles are finely crushed. The grit-bone-tempered and grog-grit-bone-tempered sherds may be from Mill Creek Plain, since that gritty pottery has been described as having a mixture of tempers, including clay particles, quartz grains, shale, mica, and charred organics, although Early (1988:64) does not mention charred bone as a temper inclusion. It is probably more likely that these sherds simply represent undecorated sherds from untyped Caddo vessels.

The three plain rims have direct or vertical rims (see Figure 9h-i), and two have rounded lips and the third has a flat lip. The rounded lip sherds have shell or grog-grit-temper, and are probably Caddo vessels, as is the flat lip. This sherd is tempered with grog-grit-bone.

Incised sherds comprise $60 \%$ of the decorated sherds, followed by punctated (35\%), engraved (6\%), and brushed (6\%). Most of the decorated sherds are tempered with grog (47\%), and $15 \%(n=8)$ of the grog-tempered sherds from the site have decorations. Other decorated sherds are tempered with grit $(n=2)$, possible shell $(n=2)$, grit-grog-bone $(n=2)$, grog-grit $(n=1)$, grog with a sandy paste $(\mathrm{n}=1)$, and bone $(\mathrm{n}=1)$. Decorated sherds are also common among the possible shelltempered sherds (29\%), the grit-grog-bone (50\%), and bone-tempered (33\%) sherds. The relatively high frequency of decorated sherds, in combination with the quantities of plain and decorated sherds with grog-tempering $(69 \%)$ or shell-temper $(5.5 \%)$, indicate that the ceramics from the Cox Creek site were primarily made by Caddo groups after ca. A.D. 900. The OCR dates from the midden deposits where most of the sherds were found further suggests that the Caddo occupation at the Cox Creek site took place primarily between A.D. 1050-1450, during the Early and Middle Caddo periods. The presence of plain and decorated shell-tempered sherds points to a limited use of the site after ca. A.D. 1450, based on the dating of Late Caddo components at the Standridge and Winding Stair sites in the southern Ouachita Mountains with similar shell-tempered pottery (see Early 1988; Early et al. 1999).

Because of the small size of most of the decorated sherds, it is difficult to determine in most cases if the nine incised sherds are Class A or Class B examples. One grog-tempered Class A body sherd from Looter Hole 20 has diagonally opposed incised lines, probably from a Military Road Incised jar, and a sandy paste Class B rim sherd from ST 589 has at least two rows of horizontally incised lines below the lip; the lines are widely spaced (3.6 $\mathrm{mm}$ apart). Five other incised sherds have broad ( $2 \mathrm{~mm}$ wide) incised lines; in four cases, the decoration is only a single incised line (see Figure 9a). One grog-tempered body sherd has at least five broad parallel incised lines (see Figure 9e). Two other sherds (ST 568 and Looter Hole 22) have fine-line incised decorations, with at least 2-6 parallel lines (see Figure 9d). Both of these sherds are tempered with grog.

The Class $\mathrm{C}$ punctated sherds have fingernail punctations. Two with grog and grit temper have at least two rows of deep fingernail punctations (see Figure 9c), and these (from ST 568 and Looter Hole 26) are probably from the body of Military Road Incised jars. Two others with grogtemper (ST 562 and ST 597) have fingernail punctations, although it is not clear if they occur in rows or are randomly spaced across the vessel body. The last two Class $\mathrm{C}$ punctated sherds are from probable shell-tempered flaring rim cooking jars that have horizontal rows of vertically-placed fingernail punctations. Early (1988:82 and Figure 42) describes similar shell-tempered jars (untyped, Group 3) from Late Caddo contexts at the Standridge site, and she notes that "[u]tilitarian jars of this shape with punctated or incised rims and undecorated bodies are well represented in 
both upper Ouachita and middle Ouachita drainage collections."

The one Class D (see Schambach et al. n.d.) body sherd is tempered with grog and has parallel brushed marks on the vessel exterior surface (see Figure 9g). The vessel-probably a cooking jar-was smoothed on the interior, presumably to lower its permeability and increase its resistance to thermal shock (Rice 1996:148; Schiffer et al. 1994:210).

A single Class E engraved body sherd from ST 568 has a zone of fine cross-hatching (see Figure 9f). This sherd appears to be from a carinated bowl, and may be an unspecified variety of Friendship Engraved.

A small amount of burned animal bone was recovered in the shovel testing in the midden. Two pieces of burned bone were in ST $562(28-40 \mathrm{~cm})$.

\section{Crow Road Site (3CL749)}

The Crow Road site is an extensive prehistoric site with Middle Archaic and Early-Middle Caddo components on a relatively broad and flat ridge (410-440 feet amsl) in a prominent meander loop in the Caddo River. The site covers about $98,800 \mathrm{~m}^{2}$, and is bounded by the Caddo River on three sites; to the north the ridge crests at 470 feet amsl, and there are two small tributaries in that area. This relatively low-lying area may represent a filled-in old channel of the Caddo River.

The landform is covered with pines and hardwoods, and surface visibility is poor. The eastern part of the ridge has been recently clear-cut by the Vicksburg District to control an insect infestation, and the understory is a thick growth of vines and briars; the area has also been replanted in pine seedlings. The ridge has also been previously cultivated, as there are agricultural terraces spaced 30-40 m apart across the landform. The southern and westernmost portions of the site may also have been periodically inundated by DeGray Lake.

Thirty-two of 44 shovel tests we excavated at the Crow Road site contained prehistoric lithic and/or ceramic artifacts, with an overall density of 4.9 artifacts per positive shovel test. The Pirum-Sherless-Shermore sediments range from 10-45 cm in thickness.

Prehistoric tools include a Middle Archaic net sinker or grooved stone from ST 754, a thick biface from ST 746, and a corner-notched arrow point and arrow point preform from ST 747. The latter is associated with grog-tempered and grog-grit-tempered plain pottery sherds and fire-cracked rocks. Three other shovel tests also have prehistoric Caddo ceramics, and they cluster on the higher part of the ridge (430-440 feet amsl), and one of these shovel tests (ST 777) also has fire-cracked rock.

There are three areas within the site that have higher densities of prehistoric lithic debris (between 8-17 flakes per shovel test). The first (ST 748 and ST 750) is directly associated with the prehistoric ceramics, and immediately east of the shovel test with the corner-notched arrow point and the arrow point preform of pink novaculite, while the second (ST 756) is in the center of the site; two bifacial cores were also recovered in the shovel testing in this area. The third area with high densities of lithic debris is along the eastern margins of the site (ST 760 and ST 762), immediately east of another area with prehistoric Caddo ceramics.

At the Crow Road site, there are nine sherds from four different shovel tests; the overall site density based on the shovel testing is 3 sherds per square meter. The nine sherds include one sherdlet (i.e., less than $1 \mathrm{~mm}$ in length and width), seven body sherds, and one plain rim sherd. 
The rim is grog-tempered, and is direct with a rounded lip; it is $5.9 \mathrm{~mm}$ in thickness. One of the body sherds (from ST 752), also grog-tempered, has a 2-mm wide and broad incised line (see Figure 9b). Both of these sherds are from vessels that were fired in a reducing environment. Three other plain and unsmoothed grog-tempered sherds are relatively thick-7.5-8.2 mm-and are probably from Williams Plain vessels. Each sherd is from a different vessel, one oxidized during firing, another incompletely oxidized, and the last fired in a reducing environment, but cooled in high oxygen conditions.

Two other plain body sherds have grog and grit-tempering, and one has a gritty feel. The body sherds range from 5.8-7.9 $\mathrm{mm}$ in thickness. The mixture of tempers, and the gritty or sandy paste suggests these sherds may be from Mill Creek Plain vessels (see Early 1988). Both sherds are from vessels that were reduced during firing, but cooled in the open air.

The final sherd is a relatively thin $(6.4 \mathrm{~mm})$ plain body sherd with grog, bone, and grit temper inclusions; neither the exterior or interior surfaces have been smoothed or burnished. It is also from a vessel that was fired in a reducing environment, but cooled in a high oxygen environment.

\section{Lake Ouachita, Montgomery County}

\section{Lonesome Loblolly (3MN2157)}

The Lonesome Loblolly site is a multi-component prehistoric site on a long and relatively narrow alluvial terrace (576-590 feet amsl) along Twin Creek, a tributary to the Ouachita River. Site size is estimated at 25,000 square meters (6.25 acres). There is an old creek channel along the western end of the site, and there are small streams at the northern and southern ends of the landform. At the southern and southwestern part of the site, the terrace cut is 3-4 $\mathrm{m}$ in height.

One relatively open area in the southwestern part of the Lonesome Loblolly site contains prehistoric ceramic sherds. The area is marked by a small rise approximately $30 \mathrm{~m}$ in diameter and $1 \mathrm{~m}$ in height, covered with grasses, briars, and vines, and a few hardwoods and pines. Overall, surface visibility ranged from 10-25\% across the site, with the highest visibility along the shoreline. Vegetation here includes hardwoods, a few pines, and a thick understory of grass, briars, and vines.

A total of 36 shovel tests were excavated at the Lonesome Loblolly site, and 23 contained prehistoric lithic and/or ceramic artifacts in the Kenn fine sandy loam sediments. The majority of shovel tests have prehistoric artifacts between $0-20 \mathrm{~cm}$ bs, but two at the northern and southwestern parts of the site have $30-40 \mathrm{~cm}$ thick deposits. The density of prehistoric lithic artifacts is 2.30 per positive shovel test, and includes one Marshall dart point in a shovel test. The highest densities of prehistoric lithic artifacts occur in the central part of the site (in three shovel tests), and this area also has fire-cracked rock. The proximity of the Marshall dart point to these three shovel tests suggests this part of the site probably has a spatially discrete Late Archaic component.

The prehistoric ceramics were recovered between 0-20 cm in three other shovel tests (ST 98, 100, and 101), and the prehistoric ceramic density is 1.67. Four of the sherds are plain, and one has fingernail punctations. All five sherds are from vessels fired in a reducing environment, although $75 \%$ were subsequently cooled in a high oxygen environment. Three of the sherds have grog temper, including the one from ST 100 with a row of fingernail punctations, are relatively thin $(5.93 \pm 0.44 \mathrm{~mm})$, and have been smoothed on exterior surfaces. One sherd has grit temper (7.4 $\mathrm{mm}$ thick), and the last sherd has both grog and grit aplastics $(5.7 \mathrm{~mm})$. None of the sherds have 
a sandy or gritty paste, which indicates they are not from the prehistoric Caddo Mill Creek Plain wares (see Early 1988), or earlier Woodland period pottery (see Schambach 1998). Rather, these sherds appear to be from untyped Caddo vessels of Early to Middle Caddo age, based on the thin body walls of the vessels, and the predominance of grog temper. The absence of shell-tempered pottery here suggests the Lonesome Loblolly Caddo component predates ca. A.D. 1450 (cf. Early 1988, 2000).

A Marshall dart point (see Schambach 1998:Figure 29) of grayish-white novaculite was found in ST 81 (0-20 cm bs) in the northern part of the Lonesome Loblolly site. The point is parallel-stemmed, with a flat base, deep corner-notching, and long barbs. Transverse and longitudinal fractures have removed most of the blade and one barb of the point. It has a $18.3 \mathrm{~mm}$ stem width and is $7.2 \mathrm{~mm}$ thick. Schambach (1998:Table 20) suggests that Marshall points in Southwest Arkansas date to the latter part of the Middle Archaic, between 2000-3000 B.C., but in Central Texas, where the Marshall point was defined, they appear to be later in time, from ca. 500-0 B.C. (Collins 1998:Figure 4-1). In either case, the Marshall point at the site clearly signifies an earlier pre-Caddo use of the northern part of the Lonesome Loblolly site.

The lithic debris from the Lonesome Loblolly site is dominated by novaculite $(98 \%)$, particularly white novaculite. There is a single small non-cortical piece of Big Fork chert. White novaculite lithic debris comprises $86 \%$ of the novaculite, along with small amounts of gray $(n=5)$ and yellow $(n=2)$ novaculite. More than $83 \%$ of the lithic debris are medium to small in size according to the size grade data, and they are non-cortical (see Perttula and Nelson 2001: Appendix 2). This points to tool resharpening and maintenance activities during Archaic and Caddo occupations, as well as the secondary reduction of cores and bifaces/preforms instead of larger cobbles or slabs from quarry sites or river gravels.

Two pieces of sandstone FCR $(0.7 \mathrm{~kg})$ were found in ST $89(0-20 \mathrm{~cm} \mathrm{bs})$ and ST $103(0-20$ $\mathrm{cm}$ bs) at opposite ends of the site. They probably represent the remains of "hot rock" cooking and baking of plant foods and/or the mass processing of nut mast.

\section{Roundup (3MN2158)}

The Roundup site is situated on a large alluvial terrace (576-580 feet amsl), with Twin Creek to the south, and a small tributary to the north. It has deep (at least $40-80 \mathrm{~cm}$ thick to more than $100 \mathrm{~cm}$ in thickness) and very compact Speer fine sandy loam sediments, and the archeological deposits at the site are 2-3 times thicker than any of the other prehistoric or historic archeological sites in this Lake Ouachita survey project. Along the northern end of the terrace, a 3-4 m high cut bank is present, with a small stream at the base of the embankment separating the Roundup and Lonesome Loblolly sites.

Surface visibility across the site is less than $10 \%$, with thick grasses and hardwoods. The landform is currently being used as a wildlife food plot, and has recently been tilled and disc plowed with seed grasses being planted. These grasses were $15-20 \mathrm{~cm}$ tall at the time of the archeological survey. This tilling and disc plowing had disturbed at least the upper $20 \mathrm{~cm}$ of the archeological deposits, and the site has also been eroded from lake level fluctuations.

The Roundup site is about 20,000 square meters in size (5 acres). Eight of the 11 shovel tests excavated here contain prehistoric artifacts, and six also have prehistoric ceramic artifacts. The density of artifacts is 4.13 for prehistoric lithics, and 4.33 for prehistoric ceramic sherds. Six shovel tests have archeological deposits that are more than $40 \mathrm{~cm}$ in thickness, and in one (ST 107) the archeological materials were $80 \mathrm{~cm}$ deep. The other positive shovel tests had archeological materials only between $0-20 \mathrm{~cm}$ bs. 
The highest densities of prehistoric lithic artifacts occur in ST $107(n=11)$ and ST $109(n=6)$ in the northeastern and eastern parts of the site (see Perttula and Nelson 2001: Appendix 2), near Twin Creek. The prehistoric ceramics, on the other hand, are most abundant in ST $110(\mathrm{n}=11)$ and ST $112(n=5)$ in the northern and central parts of the terrace.

The lithic debris includes novaculite ( $\mathrm{n}=29$ or $88 \%$ ), quartz $(\mathrm{n}=3$ or $9 \%$ ) and Big Fork chert $(\mathrm{n}=1)$. Among the novaculite, the chalky white-colored raw material is the most abundant $(\mathrm{n}=21$ or $72 \%$ of the novaculite lithic debris), with smaller amounts of white-red $(n=1)$, white-gray $(n=3)$, gray $(n=3)$, and pink $(n=1)$ colors. The flakes are medium $(45 \%)$ to large $(42 \%)$ in size, and only $3 \%$ have cortex. This suggests that the secondary reduction, production, and shaping of bifaces or flake tools occurred here after cortex had been removed elsewhere (perhaps at a quarry location).

Including the single sherd found on the surface (see below), a total of 27 prehistoric ceramic sherds were recovered during our investigations at the Roundup site. Only a single sherd from ST $112(0-20 \mathrm{~cm} \mathrm{bs})$ is decorated, and it has two parallel and finely incised or engraved lines; it is grit-tempered. The sherds are tempered with grit $(n=5)$, bone-grog $(n=1)$, grog $(n=9)$, and grog-grit $(n=11)$. Two of the grog-tempered sherds have a noticeable sandy paste.

The grog-grit-tempered sherds are thin $(5.97 \pm 0.99 \mathrm{~mm})$, and lack any form of surface treatment. In some cases the grit is comprised of crushed pieces of quartz, as well as other kinds of rock (including hematite). More than $90 \%$ of the sherds are from vessels that were fired in a reducing environment (cf. Teltser 1993). This gritty pottery is probably the Early to Middle Caddo ware Mill Creek Plain, since it has been described by Early (1988) as containing a mixture of tempers, including clay particles, quartz grains, shale, mica, and charred organics. The grit-tempered sherds may be from the same ware, which is suggested in part because they do not have sandy paste; grit-tempered and sandy paste sherds seem characteristic of Ouachita Ironware, a Woodland period ceramic ware (see Early 1988; Schambach 1998). These sherds are also rather thin $(5.74 \pm$ $0.34 \mathrm{~mm}$ ), lack any surface treatment, and $80 \%$ are from vessels fired in a reducing environment. As previously mentioned, the one decorated sherd (parallel incised body sherd) was tempered with grit.

The grog-tempered sherds are too thin $(6.08 \pm 0.45 \mathrm{~mm})$ to be classified as Williams Plain, which is usually quite a bit thicker (see Schambach 1998:25), and they likely belong to an untyped Caddo ware. One of the sherds has been well-smoothed on the interior surface, and they are all from vessels that were fired in a reducing or low oxygen environment. The grog-tempered sherds with sandy paste are also very thin-walled $(5.2 \pm 0.1 \mathrm{~mm})$, and are from vessels fired in a reducing environment.

Finally, the one sherd with bone and grog temper is $6.9 \mathrm{~mm}$ thick and has no surface treatment. It is from a vessel that was fired and cooled in a low oxygen environment.

A single body sherd $(6.0 \mathrm{~mm})$ of grit-tempered pottery was found on the surface near ST 110. It is from a vessel that was fired in a reducing environment, and neither the exterior or interior surfaces had any surface treatment.

Taken as a group, the small assemblage of prehistoric ceramics appear to be from an Early to Middle Caddo occupation at the Roundup site. The absence of shell-tempered sherds suggests the occupation pre-dates A.D. 1450 (see Early 1988, 2000). A similar but larger ceramic assemblage has been documented from the Cox Creek site (3CL739) on the Caddo River, where 69\% of the sherds have grog-tempering, and about $65 \%$ of the sherds were from vessels that were fired in a reducing environment (Perttula and Nelson 2000:158-161). Based on the OCR dates from the midden deposits at the Cox Creek site (see Table 2), the Caddo occupation there took place 
primarily between A.D. 1050-1450.

\section{$3 M N 2185$}

This extensive prehistoric and historic archeological site is on a broad alluvial terrace (ca. 580 feet amsl) about $50 \mathrm{~m}$ north and east of Lake Ouachita. The now-inundated channel of the Ouachita River is ca. $300 \mathrm{~m}$ south of 3MN2185. Intermittent tributaries of the Ouachita River mark the northern and northeastern parts of the site. Vegetation across the site varies from hardwoods and cedar trees in Area A, with a dense understory of briars and vines, to mature pines and less undergrowth across the remainder of the site. Surface visibility is uniformly poor.

The soil at 3MN2185 is classified as Avilla silt loam, 1-8\% slopes. A representative shovel test profile from ST $0 \mathrm{~N} 0 \mathrm{E}$ in the northeastern part of the site indicates at least $17 \mathrm{~cm}$ of silt loam overlying a reddish-brown clayey silt between $17-35 \mathrm{~cm}$ bs. In Area A, the silt loam is thicker-perhaps as thick as $50 \mathrm{~cm}$-with an increased amount of clay below $40 \mathrm{~cm}$ bs.

Site 3 MN2185 covers a $300 \times 220 \mathrm{~m}$ area, based on the extent of the landform and the excavation of 102 shovel tests across the alluvial terrace (Perttula and Reese 2002). Seventy-seven shovel tests contained prehistoric and/or historic artifacts. The prehistoric artifact density is 20.0 per positive shovel test. There are four areas on the alluvial terrace with higher concentrations of prehistoric artifacts. The first is in the southeastern part of the terrace (around 90S 30E), while the other three areas are along the western and central part of the terrace, centering around $60 \mathrm{~N}$ $100 \mathrm{~W} ; 0 \mathrm{~N} 120 \mathrm{~W}$; and Area A. The highest densities of both prehistoric and historic artifacts is in Area A, and this is the only area that contains prehistoric ceramic sherds.

A total of 1537 prehistoric artifacts were recovered in the archeological survey investigations at 3MN2185, including a relatively large sample of prehistoric ceramic sherds, all from Area A (Table 4). These prehistoric materials were found between $0-50 \mathrm{~cm}$ bs, with a mean depth of ca. $32 \mathrm{~cm}$ bs for the 77 positive shovel tests.

Table 4. Summary of the prehistoric artifacts from 3MN2185.

\begin{tabular}{ll} 
Artifact Category & Frequency \\
\hline Lithic Debris & 1454 \\
Core & 5 \\
Utilized Flake Tool & 16 \\
Retouched Flake Tool & 4 \\
Dart Point & 6 \\
Bifacial Tool Fragment & 5 \\
Thin Biface & 5 \\
Thick Biface & 1 \\
Bifacial Preform & 1 \\
Quartz Crystal & 1 \\
Fire-cracked Rock & \\
Ceramic Sherds & 41 \\
\end{tabular}

The ceramic sherds from 3MN 2185 include 26 sherds and five sherdlets (pieces less than $1 \mathrm{~cm}$ in length and width) from six different shovel tests in Area A (Table 5). The decorated sherds are found only in two shovel tests, both in the central part of Area A, and another shovel test in 
the same area had the highest density of plain sherds. Overall, the sherd density in Area A is 4.33 per shovel test with ceramics.

Table 5. Inventory of ceramic sherds.

\begin{tabular}{llccc}
\hline Provenience & Depth & Decorated Sherds & Plain Sherds & Sherdlets \\
\hline ST 0N 0E* & N/A & 1 & - & - \\
ST 10N 0E* & $0-30 \mathrm{~cm}$ & 7 & 3 & 1 \\
ST 0N 5W* & $20-40 \mathrm{~cm}$ & - & 9 & 1 \\
ST 10N 25W* & $0-30 \mathrm{~cm}$ & - & 3 & 1 \\
ST 10S 0E* & $0-50 \mathrm{~cm}$ & - & 1 & - \\
ST 40S 130W+ & $0-30 \mathrm{~cm}$ & - & & \\
\hline
\end{tabular}

*Area A grid; +=Shovel transect grid; Area A coordinates would be 40N 15W

All 26 of the sherds are tempered with grog (Table 6) and have a clay paste. Most of these sherds are also tempered with grit or crushed rock (58\%), and another sherd has been tempered with grog and bone. One sherd from ST 0N 5W had grog temper and a significant amount of charred organics/charcoal in the paste. A small number of the sherds in the assemblage have been smoothed, burnished, or scraped/wiped on interior and/or exterior surfaces, and the preservation of residue deposits on several sherds indicate that vessels at the site were used for cooking purposes.

Table 6. Ceramic attribute analysis, 3MN2185 sherds.

\begin{tabular}{|c|c|c|c|c|}
\hline Grog & \multicolumn{2}{|c|}{ Grog-organics } & Grog-bone & Grog-grit \\
\hline No. & 1 & & 1 & 15 \\
\hline Smoothed & 1 & - & - & - \\
\hline Burnished & 1 & - & - & 1 \\
\hline Scraped/Wiped & - & - & - & 2 \\
\hline Organic Residue & - & - & - & 2 \\
\hline Incised & 3 & - & - & 5 \\
\hline Oxidized Firing & 1 & & & 1 \\
\hline Reduced Firing & 8 & 1 & 1 & 14 \\
\hline $\begin{array}{l}\text { Mean Thickness } \\
(\mathrm{mm}) \text {, body }\end{array}$ & $6.48 \pm 0.54$ & 6.8 & 8.2 & $7.20 \pm 0.66$ \\
\hline $\begin{array}{l}\text { Mean Thickness, } \\
(\mathrm{mm}) \text {, base }\end{array}$ & - & - & - & $9.5 \pm 0.7$ \\
\hline
\end{tabular}

More than $90 \%$ of the sherds in the 3MN2185 assemblage are from vessels fired in a reducing environment (see Table 6). Furthermore, most of these vessels were then cooled in a high oxygen environment (i.e., pulled out of the fire to cool, rather than allowed to cool in the fire as it died out). The high frequency of sherds and vessels fired in a reducing environment is typical of prehistoric Caddo Indian ceramic assemblages across the Caddoan area and in Caddo ceramic assemblages from the Ouachita Mountains in southwestern Arkansas. For example, in Caddo ceramic assemblages with between 30-250 sherds dating between ca. A.D. 1050-1500+ from Lake Greeson, Lake Ouachita, and DeGray Lake (Perttula and Nelson 2000, 2001, 2002), between 55-93\% of the sherds are from vessels fired in a reducing environment. Vessel sherds range between 6.48-8.2 
$\mathrm{mm}$ in average thickness along the body walls, and the two base sherds are about $9.5-10.0 \mathrm{~mm}$ in thickness (see Table 6).

The eight decorated sherds are incised (see Table 6), and these sherds appear to be from two different utility ware vessels, one tempered with grog and the other tempered with grog-grit. The sherds have parallel to opposed incised lines on the vessel, and the incised lines are broad and shallow, almost trailed. In several instances, the incised lines have been partially to almost totally smoothed and obliterated from the vessel surface. Given the use of grog temper, the incised decorations (resembling Military Road Incised), the relatively thin and well-made vessel bodies, and the frequency of sherds from vessels fired in a reducing environment, it is likely that the 3MN2185 ceramic assemblage is from a prehistoric Caddo Indian assemblage. If the identification of possible Military Road Incised sherds is correct, then the ceramic-bearing occupation at the site took place in the $14^{\text {th }}$ and $15^{\text {th }}$ centuries A.D.

The dart points from 3MN2185 are Middle to Late Archaic in age, including one sidenotched piece (ST 90S 60E, 0-30 cm bs), one expanding stem form (ST 0N 110W, 0-43 cm bs), and two with parallel stems and flat to slightly concave bases (ST 0N 130W, 0-40 cm bs and 40S $130 \mathrm{~W}, 0-30 \mathrm{~cm}$ bs). The dart points occur in three of the four areas with the highest concentrations of artifacts, namely in the central, southwestern (Area A), and southeastern parts of the site.

The fragmentary side-notched form of white novaculite has a flat base, but with no edge grinding, and a longitudinal fracture down the blade and stem; it is $4.9 \mathrm{~mm}$ thick and has a 13.0 $\mathrm{mm}$ stem width. The blade of the expanding stem form, of Big Fork chert, has been reworked into a drill, and the tip of the drill has subsequently been broken during use. The point has a flat to convex blade. It is $27.0 \mathrm{~mm}$ wide and $7.6 \mathrm{~mm}$ thick, with a $20.6 \mathrm{~mm}$ stem width.

The two parallel-stemmed points, one of quartzite and the other of gray novaculite, are probably Bulverde points, dating ca. 2500-2000 B.C. (Schambach 1998). They are relatively thick (9.4-10.8 $\mathrm{mm}$ ), with stems that range from 16.0-19.8 $\mathrm{mm}$ in width; one has a resharpened blade.

The other two dart points are tips of broken specimens. One is gray novaculite (ST 10S $80 \mathrm{~W}$ ) and the second is white novaculite (ST 95S 130W).

Other bifacial tools include four bifacial tool fragment, one thick biface, and five thin bifaces. All of these chipped stone tools were made from either gray or white novaculite, and they are concentrated in the central and southwestern (Area A) parts of the alluvial terrace.

Flake tools are represented by four retouched flake tools, 16 utilized flake tools, and a single perforator. More than $90 \%$ of these tools - probably used for the cutting and shredding of plant and animal remains - were made from novaculite, and the remainder were made from Big Fork chert. The novaculite included white $(n=8)$, gray $(n=8)$, white-red $(n=1)$, pink $(n=1)$, and gray-black $(n=1)$ colors. The flake tools are found in each of the high artifact density areas, but are particularly concentrated in Area A and the central part of the alluvial terrace.

One apparently worked and/or utilized quartz crystal (measuring 79 x $42 \mathrm{~mm}$ ) was found in ST 80S 100W, or Area A. The function of the piece is not known.

The lithic debris includes five novaculite cores and 1454 flakes and shatter. The highest densities of these materials was in Area A, where some shovel tests had more than 100 pieces of lithic debris (i.e., densities of ca. 1000 per square meter). Tertiary flakes $(n=1353)$ accounted for 93.1\% of the lithic debris, followed by secondary decortication flakes $(n=69,4.7 \%)$, thinning flakes $(\mathrm{n}=11,0.8 \%)$, shatter $(\mathrm{n}=9,0.6 \%)$, primary decortication flakes $(\mathrm{n}=6,0.4 \%)$, blade flakes $(\mathrm{n}=4$, $0.3 \%)$, and indeterminate flakes $(n=2,0.1 \%)$. The great abundance of tertiary flakes, and the very few thinning or cortical flakes, indicate that the lithic knapping at 3MN2185 focused on the final shaping, edge-trimming, and resharpening of completed or near-completed tools. The reduction 
of cores and cobbles, and the removal of the cortex or rind, apparently took place at other locations, including quarries, gravel bars, and other lithic raw material source areas in this part of the Ouachita Mountains.

Almost $93 \%$ of the lithic debris is novaculite, by far the most abundant and knappable lithic raw material in the Ouachita Mountains. Most of the novaculite is white $(n=508,35.0 \%)$ or gray $(n=795,54.7 \%)$, but a wide range of different colors are represented in the 3MN2185 lithic debris assemblage: pink $(n=23)$, red $(n=8)$, black $(n=6)$, gray-black $(n=5)$, brown $(n=3)$, white-black $(\mathrm{n}=2)$, and yellow. Various cherts comprise only $2.5 \%$ of the assemblage, and these few pieces are dominated by Big Fork chert $(n=27)$. Other chert colors are gray $(n=4)$, gray-brown $(n=1)$, white $(n=1)$, yellow-gray $(n=1)$, red $(n=1)$, and brown $(n=1)$. Quartzite lithic debris $(n=49)$ comprises $3.3 \%$ of the assemblage, and quartz $(n=15)$ and siliceous shale $(n=3)$ round out the lithic debris sample from $3 \mathrm{MN} 2185$.

A few pieces of fire-cracked rock and/or heat spalls, all of quartzite or quartzitic sandstone, were recovered in four shovel tests at 3MN2185. Two of the shovel tests were in Area A, and the others were in the northeastern part of the landform (i.e., ST 0N 20W and ST 10N 30W). Their occurrence suggests that heating and cooking features may be preserved in the site's archeological deposits.

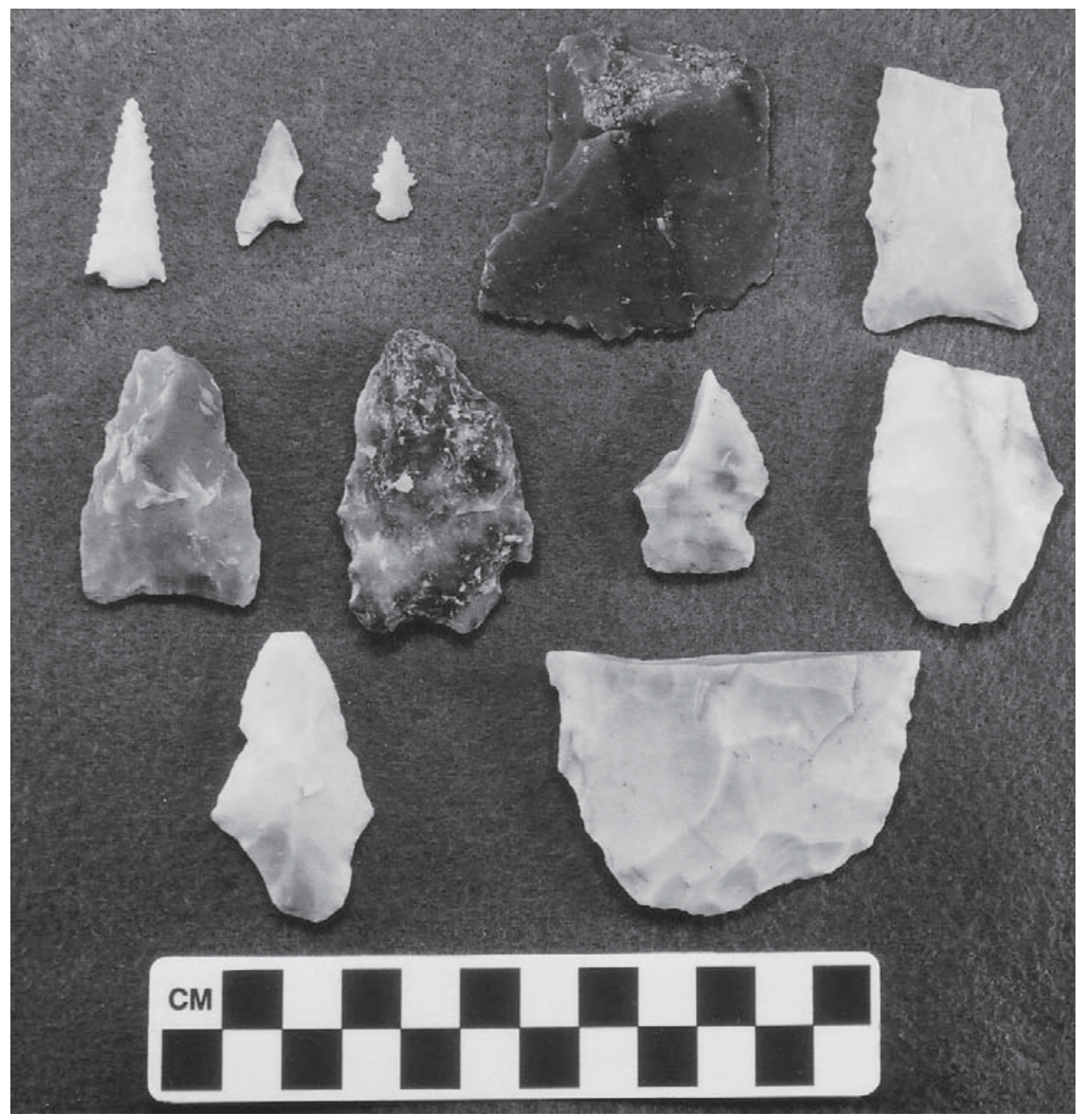

Figure 10. Chipped stone tools from Lake Greeson sites: a, c, 3PI402; b, f, 3PI383; d, 3PI381; e, 3PI388; g, 3PI375; h, k, 3PI87; i, 3PI390; j, 3PI147. 


\section{Lake Greeson, Pike County}

\section{Gentry Site (3PI87)}

The Gentry site is a large (50,000 square meters or 12.5 acres $)$ multi-component prehistoric occupation on an upland slope and low terrace (550-600 feet amsl) in the Arrowhead Point Public Use Area at Lake Greeson. Both landforms are wooded, with fair surface visibility (26-50\%) due in large measure because of erosion due to modern recreational activities. The Public use Area has several paved roads, a boat launch area at the southern end of the site on the low terrace, as well as comfort stations, picnic tables, and parking areas.

In the western part of the site, erosion is extensive, and there do not appear to be any intact archeological deposits here because the Sherless-Littlefir-Nashoba sediments have been eroded away. In the remainder of the Gentry site, however, the archeological deposits appear to be intact, and range in depth from $10-55 \mathrm{~cm}$ bs. At the northern part of the site in the vicinity of a comfort station - surveyed by Heartfield, Price, and Greene, Inc. (1980) and the archeological materials here thought to have little research potential-several shovel tests contain abundant prehistoric lithic artifacts as well as fire-cracked rock; one of these shovel tests also had a side-notched dart point. The latter suggest that prehistoric burned rock features that may be Archaic in age are preserved in this part of the Gentry site.

In the southern part of the site, a Late Caddo (dating after ca. A.D. 1500) midden deposit was identified in four shovel tests (ST 36, ST 108, ST 110, and ST 258), just north of the boat ramp area and between two paved park roads. The midden, a very dark brown to black sandy loam, ranges from 20-40 cm in thickness, and contains abundant lithic debris, high densities of shell-tempered ceramics, burned clay, a few chipped stone tools, including an arrow point fragment in ST 108. Overall, the Gentry site has a very high density of both lithic debris (61.57 pieces per positive shovel test) and prehistoric ceramic sherds (15.00 sherds per positive shovel test). The highest densities of these prehistoric artifacts occur in and about 25-30 m north of the Late Caddo midden area.

OCR samples were taken at $5 \mathrm{~cm}$ intervals from ST 258, beginning at $3-5 \mathrm{~cm}$ bs, and extending to $40 \mathrm{~cm}$ bs (see Perttula and Nelson 2002: Appendix 5). The first six samples are in the prehistoric Caddo midden deposit with abundant lithic and ceramic artifacts, and the seventh and eighth samples came from the clay loam subsoil $(35-40 \mathrm{~cm} \mathrm{bs})$.

The OCR dates from ST 258 are provided in Table 7. Two pedogenic markers were identified in the ST 258 column, one in the midden, and the other at the contact between the midden and the clay loam subsoil. The upper pedogenic marker dates to A.D. 1494-1520, and the lower pedogenic marker dates between A.D. 555-635. These dates suggest the accumulation of the Gentry site midden in Late Caddo times, with a period of pedogenic activity in the $6^{\text {th }}$ and $7^{\text {th }}$ centuries that may also be associated with an earlier prehistoric use of the alluvial landform.

Table 7. OCR Dates from the Gentry Site.

\begin{tabular}{lccc} 
Provenience & Pedogenic Marker & ACT \# & Calculated OCR Date (A.D.) \\
\hline $3-5 \mathrm{~cm}$ bs & - & 5984 & A.D. 1717-1729 \\
$8-10 \mathrm{~cm}$ bs & - & 5985 & A.D. 1623-1641 \\
$13-15 \mathrm{~cm}$ bs & Yes & 5986 & A.D. 1494-1520 \\
$18-20 \mathrm{~cm}$ bs & - & 5987 & A.D. 1266-1304 \\
$23-25 \mathrm{~cm}$ bs & - & 5988 & A.D. 1062-1112 \\
$28-30 \mathrm{~cm}$ bs & - & 5990 & A.D. 799-865 \\
$33-35 \mathrm{~cm}$ bs & Yes & 5989 & A.D. 555-635 \\
$38-40 \mathrm{~cm}$ bs & - & 5991 & A.D. 59-169
\end{tabular}




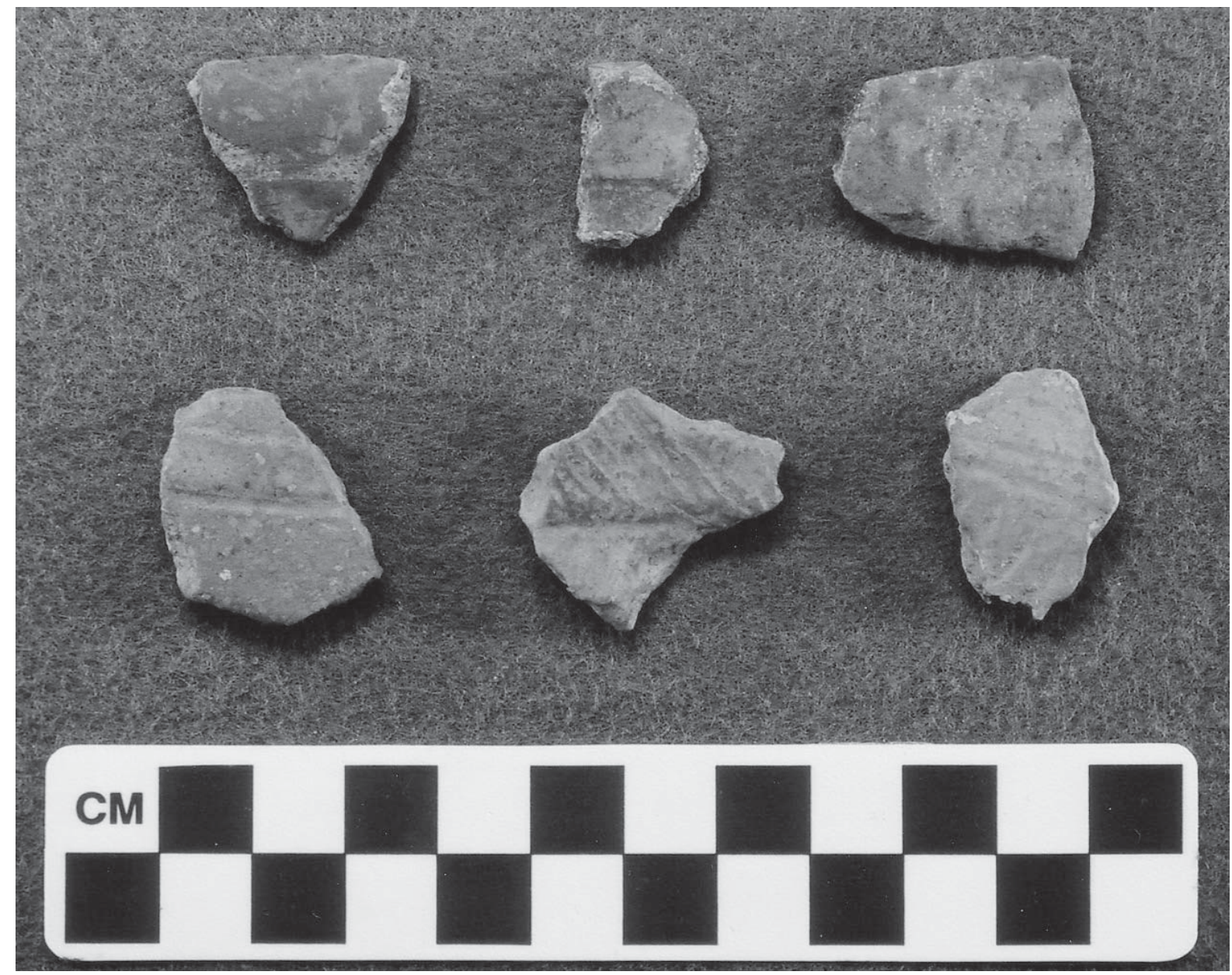

Figure 11. Decorated sherds from Lake Greeson sites: a-c, 3PI87; d, 3PI146; e-f, 3PI402.

The one arrow point in the Late Caddoan midden (ST 108, 20-40 cm bs) is fragmentary, but appears to have an expanding stem, corner notches, and a concave base. It is made from a heat-treated novaculite.

A Big Sandy dart point (Figure 10h) was recovered in the northern and probably Archaic part of the site from ST $41(20-30 \mathrm{~cm}$ bs). The point has small side notches and a flat base, and was made from a gray novaculite. It has a resharpened blade that was subsequently broken by an impact fracture. Big Sandy points date to the Middle Archaic, at about 3000 B.C. (Schambach 1998).

There are two flake tools in the lithic assemblage from the Gentry site (see Perttula and Nelson 2002: Table 5). Both have unilateral retouch and use wear (effective use wear lengths range from 17.5-26.0 mm). The flake tool from ST $36(20-40 \mathrm{~cm} \mathrm{bs})$ is a non-cortical gray novaculite hard hammer flake, and the other tool is made on a soft hammer white chert flake (ST 42, 0-18 cm bs). One bifacial tool fragment was recovered in ST 39, north of the Late Caddoan midden deposit. The tool — made from a gray novaculite — had been broken by a lateral fracture during use. It had been previously resharpened and had use wear on the lateral edges of the piece.

Three bifacial preforms were collected from the surface or in shovel testing. They were made from heat-treated gray novaculite (see Figure 10k) or a non-heat-treated black novaculite, using hard hammer knapping. The cortex on all three pieces had been previously removed, probably at the location of initial reduction activities elsewhere on the site or at a raw material procurement area. 
A large assemblage of lithic debris $(\mathrm{n}=862)$ was collected from the many shovel tests at the Gentry site. More than $98 \%$ of the lithic debris is novaculite, with $1.4 \%$ Big Fork chert, and $0.3 \%$ quartzite and siliceous shale. The white $(52.8 \%)$ and red $(27.2 \%)$ novaculite colors dominate the lithic debris, which is generally the case at all the Lake Greeson sites with more than 150 pieces of lithic debris (see Perttula and Nelson 2002: Table 8). Other novaculite colors present are gray $(15.5 \%)$, white-gray $(0.2 \%)$, white-black $(0.3 \%)$, white-red $(0.7 \%)$, yellow $(0.6 \%)$, black $(0.3 \%)$, brown $(0.5 \%)$, and black-gray $(0.1 \%)$.

The percentage of cortical flakes is only $4.7 \%$ for the site as a whole, but the frequency of larger size graded flakes $(2.54 \mathrm{~cm})$ with cortex $(40.7 \%)$ is among the highest of any of the Lake Greeson sites (see Perttula and Nelson 2002: Table 9). Conversely, the percentage of cortical flakes among the medium and small pieces of lithic debris is among the lowest of the Lake Greeson sites (0-2.3\%, respectively). Almost $80 \%$ of the lithic debris from the Gentry site are medium to small in size. The low amount of cortex, almost exclusively found on large flakes, and the high proportions of non-cortical flakes of medium and small size grades suggests that a wide range of lithic reduction activities took place here in the production of tools, from some cortex removal and initial thinning to the more common finishing, final shaping, and resharpening knapping activities.

There are 63 sherds and 26 pieces of burned clay (14.4 g) in the Gentry site artifact assemblage. The sherds are primarily from shell-tempered utility ware vessels, as more than $73 \%$ of the sherds are tempered with burned and crushed mussel shell. Plain shell-tempered vessels have been classified as Woodward Plain in southern and central Ouachita Mountains Caddo sites

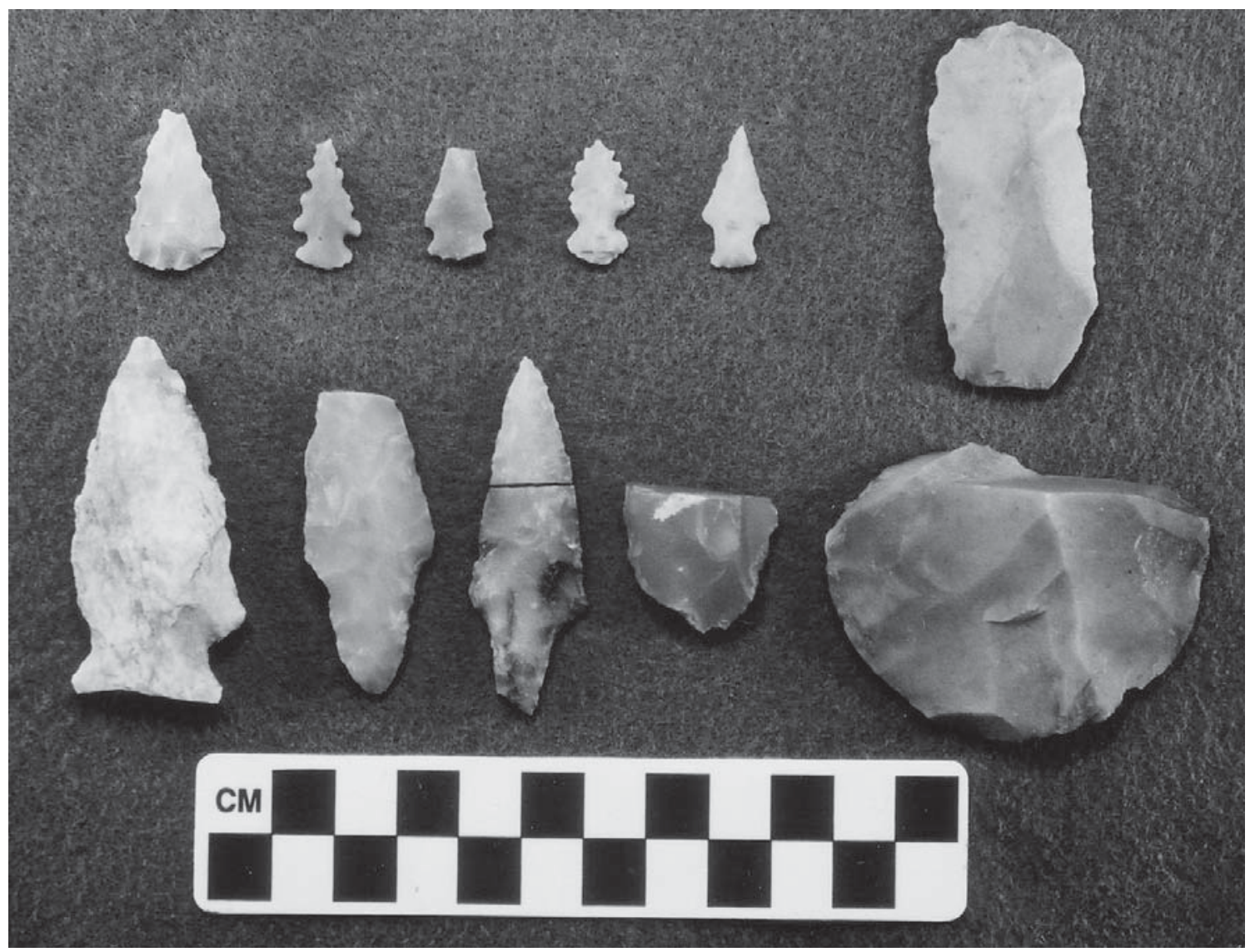

Figure 12. Chipped stone tools and a gunflint from the Star of the East site (3PI138): a, arrow point preform; $b$, Massard arrow point; c, Sequoyah arrow point; d, Sequoyah or Massard arrow point; e, Massard A point; f, endside scraper; g, Williams dart point; h-i, Gary, var. Camden dart points; j, gunflint; k, bifacial preform. 
(Early 1988:69-71, 2000:83). The high frequency of shell tempering in the ceramic assemblage is indicative of a Late Caddoan, post-A.D. 1500 occupation at the Gentry site. For example, 59\% of the ceramic sherds in the ca. A.D. 1470-1500 occupation at the Winding Stair site in the Ouachita Mountains have shell tempering (Early 2000). At the ca. A.D. 1500-1700 Helm site on the Ouachita River, $48 \%$ of the sherds have shell-tempering, and another $19 \%$ have grog and shell-tempered ceramics (Lafferty et al. 2000).

The remainder of the Gentry site ceramics are tempered with grog-grit (13.3\%), grit (6.7\%), and grog $(6.6 \%)$. Only one of the sherds with these kinds of temper inclusions was decorated-a body sherd from ST $108(20-40 \mathrm{~cm})$ with two closely-spaced parallel incised lines-and several plain body sherds were found on the surface or in the midden deposits. It is possible that these sherds represent an earlier prehistoric Caddo occupation, but it is just as likely that they are contemporaneous with the shell-tempered wares, as the change from the use of non-shell to shell tempering inclusions apparently took at least 100 years or more (cf. Early 2002a), and even though "shell becomes the overwhelming choice for temper during the [post-A.D. 1500] Social Hill phase" (Early 2002b:10), not all vessels were tempered with shell even then.

The great majority of the sherds are from vessels fired in a reducing environment $(93.3 \%)$. Only $6.7 \%$ of the sherds are from vessels that were oxidized or incompletely oxidized during firing, compared to $44.9 \%$ of the sherds from the Mid-Ouachita phase component at the Star of the East site (see below). The well-controlled firing and cooling of the Gentry site ceramic vessels-and the virtual absence of incompletely oxidized vessels - suggests they were fired for longer periods of time than in the earlier Caddo occupations. The shell-tempered vessels were thin, ranging from 4.65-4.96 $\mathrm{mm}$ in rim and body wall mean thickness, and the combination of thin and well-fired vessels suggests that they were designed to withstand thermal shocks from repeated heating and cooling episodes of vessel use in cooking activities.

Only six sherds are decorated, one previously mentioned incised body sherd with grog-grit temper, and the other five from shell-tempered vessels. A single body sherd from ST 110 (0-20 $\mathrm{cm}$ ) has at least three rows of tool punctates (Figure 11c), probably arranged in horizontal bands on cooking jars. "Such jars are well-represented in both upper Ouachita and middle Ouachita drainage collections" (Early 1988:82), and Early (1993:Figure 50d) illustrates similar decorative patterns on untyped vessels from the Late Caddo occupation at the Hardman site.

The other decorated shell-tempered sherds have one or two parallel or horizontal incisedtrailed lines on the rim (see Figure 11a-b). The rims are everted, with rounded lips, and they are from vessels that have been smoothed on interior and exterior surfaces. These sherds are from jars, and thus are not from Keno Trailed vessels (almost exclusively bottles), and the horizontal lines do not resemble any of the decorative patterns characteristic of Foster Trailed-Incised, a common Late Caddo utility ware jar in the southern Ouachita Mountains (see Early 2002b), but the sherds from the Gentry site are rather small and the entire decorative pattern is not identifiable on them.

Wood charcoal $(n=16)$, charred hickory nutshell $(n=1)$, and burned animal bone $(n=1)$ were found in ST 40 and ST 110 between $0-40 \mathrm{~cm}$ bs, and these are primarily from the Late Caddo midden deposit. The wood charcoal was prevalent from 0-29 cm bs, the one nutshell came from 20-40 $\mathrm{cm}$ bs, and the small piece of burned animal bone was recovered from 0-20 cm bs in ST 110 .

\section{Star of the East (3PI138)}

The Star of the East site is a multi-component prehistoric and historic site on an alluvial terrace (550 feet amsl) of the Little Missouri River and toe slope (560 feet amsl); between the two is a marshy area that probably represents an old channel or slough of the Little Missouri River. The old channel of the Little Missouri River is approximately $100 \mathrm{~m}$ south of the site. Vegetation on 
the toe slope is a mixture of hardwoods, with poor surface visibility (less than 10\%), except where an unimproved road bisects the landform. The low-lying alluvial terrace has hardwoods, button willows, and marsh grasses, and surface visibility is also generally poor here as well.

The alluvial terrace has been eroded along its margins by wave action and lake level fluctuations, and prehistoric artifacts are abundant along the shoreline, and in the unimproved road that crosses the toe slope and the alluvial terrace. Site size is estimated at 30,000 square meters ( 7.5 acres). The toe slope landform has shallow Sherless-Littlefir-Nashoba sediments, but the alluvial terrace has thick Ceda fine sandy loam sediments around $80 \mathrm{~cm}$ in depth.

Prehistoric lithic and ceramic artifacts are abundant in surface and sub-surface contexts at the Star of the East site. Twenty-eight shovel tests excavated here contained prehistoric artifacts. There are high densities of lithic debris (24.33 pieces per positive shovel test), and there are several different concentrations of lithic debris on the alluvial terrace and the toe slope. Dart points, arrow points, bifacial preforms, and a side scraper were also recovered in shovel testing, along with a wide assortment of chipped stone tools from surface and shoreline contexts, and these are concentrated on the alluvial terrace (from 0-60 cm bs). Chipped stone tools found on the toe slope were found only between 0-20 cm bs.

Five of the 17 dart points from nine Lake Greeson sites were found at the Star of the East site. The dart points were made through the reduction of large masses from quarry sources, bifaces, and cores of novaculite (94\%) and a local white chert. These tools were made during Late Paleoindian, Archaic, and Woodland periods.

The five dart points from the Star of the East site include three contracting stem Gary points (Figure 12h-i), an expanding stem Williams type (Figure 12g), and a parallel stemmed Jones Creek point. The relatively thin and narrow contracting stem dart points here, Gary, var. Camden, date to the Woodland period (ca. A.D. 200-700) (Schambach 1982, 1998). Two of the three points have been resharpened along the blades. The one Williams point has an expanding and flat stem, a relatively narrow blade, and small barbs. Williams points likely date from ca. 3000-4000 B.P. in the Trans-Mississippi South (see Schambach 1998), and a well-dated Williams component at the Big Eddy site in the Missouri Ozarks dates to ca. 4000 B.P. (Lopinot et al. 1998:137). The Jones Creek form (see Schambach 1998:Figure 28) has a flat base and a parallel stem. Schambach (1998:40) has commented on the similarity of Jones Creek and Marshall points, and noted that the two dart point forms have similar horizontal and vertical distributions at the Cooper site. Although not well-dated in the southern Ouachita Mountains, these forms probably date to the Late Archaic (ca. 4000-2400 B.P.). As a group, the Star of the East dart points indicate the prior to the principal prehistoric Caddo occupation, the site was also used during the Late Archaic (ca. 2000-450 B.C.) and then again in the Woodland period (A.D. 200-700).

Four arrow points (see Figure 12b-e) and a unifacial arrow point preform (see Figure 12a) were recovered in the archeological investigations at the Star of the East site (Table 8). The preform is made from a yellowish-gray chert, and the arrow points are all of gray novaculite. The four points have expanding stems and three are also corner-notched; bases range from flat to concave and convex, stem widths range from 4.9-6.9 mm, and two have serrated blades. They represent Massard, Sequoyah, and Massard A points (cf. Brown 1996).

Table 8. Arrow points from Lake Greeson sites.

\begin{tabular}{lllllllll} 
SiteProvenience & RM* & L & W & Th & SW & S & base & Type \\
\hline PI87 & ST 108, 20-40 & r NOV - & 12.1 & 2.8 & 6.9 & - & ES-CN & Unidentified \\
PI138 & surface & y-g chert24.2 & 15.3 & 5.0 & - & - & - & unifacial preform \\
PI138 & surface & g NOV 19.2 & 10.8 & 3.8 & 4.9 & + & ES-CN & Massard
\end{tabular}


Table 8. Arrow points from Lake Greeson sites (Cont).

\begin{tabular}{|c|c|c|c|c|c|c|c|c|c|}
\hline \multicolumn{2}{|c|}{ SiteProvenience } & $\mathrm{L}$ & W & Th & SW & S & base & \multicolumn{2}{|l|}{ Type } \\
\hline PI138 & surface & g NOV & - & 10.7 & 3.1 & 6.9 & - & ES-CN & Sequoyah \\
\hline PI138 & surface & g NOV & 18.5 & 10.5 & 2.9 & 4.9 & + & ES-CN & $\begin{array}{l}\text { Sequoyah or } \\
\text { Massard }\end{array}$ \\
\hline PI138 & ST $26,0-20$ & g NOV & 21.2 & 10.7 & 2.7 & 5.5 & - & ES & Massaed A \\
\hline PI383 & ST $172,0-20$ & g NOV & 21.9 & - & 2.0 & - & - & - & Maud? \\
\hline PI402 & ST $147,0-20$ & w NOV & 29.6 & 13.2 & 3.8 & 5.9 & + & $\mathrm{CN}$ & Sequoyah \\
\hline PI402 & ST $149,0-20$ & w NOV & 14.0 & 7.6 & 2.3 & 3.9 & + & ES-CN & Massaed B \\
\hline
\end{tabular}

*RM=raw material; $\mathrm{L}=$ length (in $\mathrm{mm}$ ); $\mathrm{W}=$ width (in $\mathrm{mm}$ ); $\mathrm{Th}=$ thickness (in $\mathrm{mm}$ ); $\mathrm{SW}=$ stem width (in $\mathrm{mm}$ ); $\mathrm{S}=$ serrated; $\mathrm{g}$ $\mathrm{NOV}=$ gray novaculite; $\mathrm{w} \mathrm{NOV}=$ white novaculite; $\mathrm{r} \mathrm{NOV}=$ red novaculite; $\mathrm{y}-\mathrm{g}$ chert=yellowish-gray chert; $\mathrm{ES}=$ =xpanding stem; $\mathrm{CN}=$ corner-notched

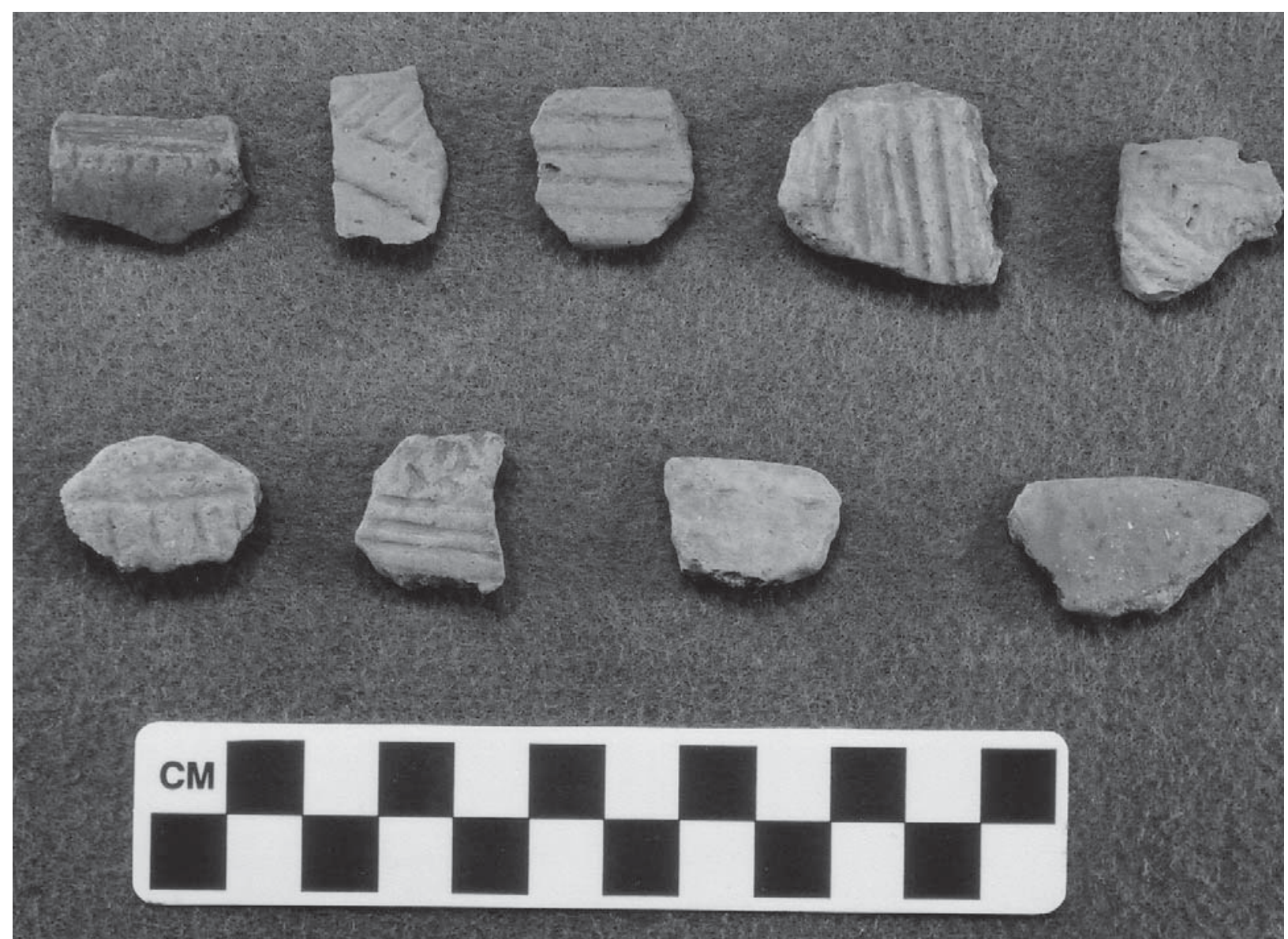

Figure 13. Decorated and rim sherds from the Star of the East site: a, Friendship Engraved; b-g, Military Road Incised; h, plain rim; i. tool punctated.

Sequoyah and Massard points appear to have been manufactured over a ca. 300-350 year period, between ca. A.D. 1100-1450 based on the chronology of burial batches at the Spiro site (Brown 1996). Guendling (2000) reports on Massard and Sequoyah points from a Middle Caddo component at the Bug Spot site (3MN979) in the southern Ouachita Mountains, and the arrow points at the Star of the East site are stylistically similar and temporally consistent with the Middle Caddo attribution. Certainly, the ceramics from the Star of the East site indicate that the principal prehistoric Caddo component dates to the Mid-Ouachita phase (ca. A.D. 1400-1500). 
Similar expanding stem and corner-notched arrow points have been recovered at two other sites at Lake Greeson (see Table 8), and these were also made from novaculite. Those from the Poppy Turner site (3PI402) also have serrated blades and relatively narrow stems.

The preform is a unifacially worked ovoid piece of yellowish-gray chert that is about 5 $\mathrm{mm}$ in thickness and $15.3 \mathrm{~mm}$ in width (see Figure 12a). It was made on a billet flake, and was ready for the final thinning and notching at the time it was discarded.

Four flake tools of novaculite were found at the Star of the East site, three from the surface and one in ST 273 (Table 9). Two have unilateral retouch/use-worn areas on large non-cortical flakes, with between 15-21.2 mm of effective use length. A third is a bifacial thinning flake with end and side scraper retouch use (see Figure 12f), and the fourth is a fragment of a side scraper. These particular tools have steep retouched and working edges (marked by small use-derived step fractures). The end-side scraper has a combined working edge length of $93.1 \mathrm{~mm}$ (see Table 9).

Table 9. Flake tools from Lake Greeson sites with Caddo components.

\begin{tabular}{llllllllll}
\multicolumn{2}{l}{ Site Provenience } & RM* & L & W & TH & FT & Crtx & UL & Location \\
\hline PI87 & ST 36, 20-40 & g NOV & 35.9 & 25.8 & 4.3 & HH & $0 \%$ & 26.0 & unilateral \\
PI87 & ST 42, 0-18 & w chert & 20.2 & 19.3 & 2.3 & SH & $0 \%$ & 17.5 & unilateral \\
PI138 & surface & y NOV & 34.0 & 23.5 & 6.1 & UID & $0 \%$ & 15.0 & unilateral \\
PI138 & surface & g NOV & 22.0 & 24.2 & 5.6 & HH & $0 \%$ & 21.2 & unilateral \\
PI138 & surface & g NOV & 55.2 & 24.2 & 8.4 & HH/BT & $0 \%$ & 93.1 & end-side scraper \\
PI138 & ST 273, 0-18 & w NOV & - & 20.0 & 6.9 & UID & $0 \%$ & $20.0+$ & side scraper \\
PI146 & surface & g NOV & 51.5 & 60.3 & 7.6 & HH & $0 \%$ & 98.0 & bilateral \\
PI372 & ST 49, 0-20 & g NOV & 56.2 & 25.0 & 5.5 & SH & $0 \%$ & 88.5 & bilateral \\
PI383 & ST 171, 0-20 & g NOV 59.2 & 46.3 & 10.3 & HH & $10 \%$ & 61.0 & bilateral
\end{tabular}

* $\mathrm{RM}=$ raw material; L=length; W=width; TH=thickness; FT=flake type; Crtx=cortex; UL=use length; y NOV=yellow novaculite; g NOV=gray novaculite; $\mathrm{w}$ NOV=white novaculite; UID=unidentified; $\mathrm{HH}=$ hard hammer; $\mathrm{BT}=$ biface thinning; $\mathrm{SH}=$ soft hammer

The flake tools are found at five Lake Greeson sites (see Table 9), primarily at sites that have prehistoric Caddo components. About $90 \%$ are made from novaculite, and typically larger hard hammer non-cortical flakes were selected for flake tool use. The unilateral flake tools have effective working edges that range from $15-26.0 \mathrm{~mm}$ in length, compared to 61-98 $\mathrm{mm}$ working edges for bilateral flake tools, and a $93.1 \mathrm{~mm}$ use length for the end-side scraper from the Star of the East site (see Table 9).

Two bifacial tool fragments were collected from the shoreline area at the Star of the East site. Both were made from a gray novaculite, and one of the pieces had been heat-treated. The two tool fragments also had use wear damage along the lateral edges, and one had also been bifacially resharpened before it was broken and discarded.

More than 230 ceramic sherds from a Mid-Ouachita phase occupation were found on the surface of the Star of the East site. This includes three plain rim sherds, 140 plain body sherds, 10 plain base sherds, and 84 decorated sherds. Eleven different shovel tests on the alluvial terrace have prehistoric Caddo ceramics between $0-60 \mathrm{~cm} \mathrm{bs}$, and the density of sherds is 2.73 per positive shovel test. There are 22 plain body sherds in the shovel tests and eight decorated sherds. More than $90 \%$ of the sherds were recovered from $0-40 \mathrm{~cm}$, however. The highest density of sherds is in ST $25(\mathrm{n}=10)$, in the central part of the terrace; one decorated piece found here is a Friendship 
Engraved, var. Freeman sherd, diagnostic of the Mid-Ouachita phase (see Early 2002a).

The Star of the East ceramic sherds are overwhelmingly tempered with grog $(81.4 \%)$, the highest percentage of grog tempering in the Lake Greeson sites with more than two ceramic sherds. Another 5.4\% have grog-grit temper, and 3.9\% are tempered with shell. Bone tempering is rare, as only $1.6 \%$ of the sherds have this aplastic, and it is generally rare at all of the Lake Greeson sites (see Perttula and Nelson 2002: Table 10).

Almost $45 \%$ of the sherds from the Star of the East site were from vessels fired in an oxidizing environment, or were incompletely oxidized during firing. These proportions are significantly different than the Late Caddo ceramic assemblage at the Gentry site (3PI87) or the Woodland period ceramics at the White Oak Creek site (3PI381). At the former, only 6.7\% of the sherds were from vessels fired under those conditions, while at the White Oak Creek site, only $10 \%$ of the sherds were fired under oxidizing or incompletely oxidizing environments. The Star of the East ceramics were not fired as long or in as well-controlled a firing environment as the vessels from these earlier or later sites.

The relatively coarse and porous grog-tempered ceramics from the Star of the East site may not have performed that effectively over an open fire, although their porosity would have helped insulate the food inside the vessel from the fire. It seems likely that more low-temperature cooking was done with the grog-tempered vessels than was the case with the thinner-walled and high fired shell-tempered vessels made later in time, but the Star of the East ceramics were generally structurally sound that could stand up to repeated heating and cooling. To offset their coarse paste and higher porosity, the grog-tempered vessels here had thicker walls to stand up to repeated heating and cooling. The grog-tempered body sherds are $6.92 \pm 0.93 \mathrm{~mm}$ in thickness, compared to the much thinner $5.64 \pm 0.61 \mathrm{~mm}$ for the shell-tempered sherds from the site. At the later Gentry site (3PI87), the shell-tempered body sherds are only $4.96 \pm 0.51 \mathrm{~mm}$ in thickness, which is almost a $30 \%$ reduction in body wall thickness.

The decorated sherds include tool punctated rows on vessel rims and bodies $(n=8)$, multiple parallel incised lines $(n=53)$, parallel and opposed incised lines $(n=1)$, curvilinear incised lines $(\mathrm{n}=1)$, single straight incised lines $(\mathrm{n}=4)$, multiple parallel incised and punctated sherds $(\mathrm{n}=12)$, cane punctated $(n=1)$, parallel brushed $(n=3)$, Friendship Engraved $(n=2)$, horizontal engraved lines $(n=2)$, curvilinear engraved lines $(n=1)$, cross-hatched engraved zone $(n=1)$, single straight engraved line $(n=1)$, parallel engraved lines $(n=1)$, and parallel and rectilinear engraved lines $(n=1)$. With one exception, these decorated sherds are on vessels made with grog-temper. The one shelltempered decorated sherd, found on the surface along the shoreline, has seven closely spaced and parallel incised lines on the vessel body.

The parallel and opposed incised (Figure 13b), multiple parallel incised (Figure 13c-d), and multiple parallel incised and punctated (Figure 13e-g) sherds are from Military Road Incised jars. These vessels are hallmarks of the Mid-Ouachita phase, and together these 66 sherds represent more than $71 \%$ of the decorated sherds from the Star of the East site. Another ceramic type that is diagnostic of the Mid-Ouachita phase is Friendship Engraved, and two carinated bowl sherds from Friendship Engraved, var. Freeman are represented in the Star of the East ceramic assemblage (Figure 13a). Both sherds were collected from ST 25 between 20-60 cm bs.

Another common decorative element are rows of tool punctates on vessel rims and bodies (see Figure 13i). These are utility ware vessels or cooking jars. About $3 \%$ of the decorated sherds have parallel brushing marks, and these may be from vessels that have versions of the Military Road Incised designs that were rendered using brushing instead of incised lines (see discussion in Early [2000:85]). About 4\% of the decorated sherds from the 14-15 ${ }^{\text {th }}$ century Standridge site 
have grog-tempered brushing (Early 1988:93), very similar to the frequency of brushed sherds at the Star of the East site.

Most of the other sherds are only small and unidentifiable decorative elements that cannot be typed. Most notably, a grog-tempered bottle sherd collected from the surface has a cross-hatched engraved zone on the vessel body, and may be from an Adair Engraved vessel. According to Early (2000:11), these bottles have "vertical bands filled with cross-hatching."

The few plain rims $(n=3)$ from the Star of the East site have direct or vertical profiles, with rounded to flat lips (see Figure 13h).

A small amount of wood charcoal $(n=1)$, charred nutshells $(n=4)$, and burned animal bone $(n=2)$ was recovered in four different shovel tests (ST 11, ST 19, ST 25, and ST 35) on the toe slope and/or the alluvial terrace, all between $0-40 \mathrm{~cm}$ bs. These remains are probably associated with the prehistoric Caddo occupation. The wood charcoal is from ST 19 (0-20 cm bs), and the nutshell is from ST $11(20-31 \mathrm{~cm}$ bs) and ST $25(20-40 \mathrm{~cm} \mathrm{bs})$. Both pieces of burned bone (ST $25,20-40 \mathrm{~cm}$ bs and ST 35, 0-20 cm bs) are from unidentifiable animals.

\section{Eden Site (3PI146)}

The Eden site was apparently occupied during the prehistoric Mid-Ouachita phase (ca. A.D. 1400-1500; see Early 2002a). The Eden site is not related culturally or chronologically to the 1840s GLO field in the vicinity-also assigned state trinomial 3PI146 by the Arkansas Archeological Survey. The latter historic field has no archeological manifestation, while the Eden site contains substantial prehistoric archeological deposits.

The prehistoric site is situated on an alluvial terrace (560 feet amsl) about $200 \mathrm{~m}$ west of the Little Missouri River, and just west of the White Oak Creek site. The two sites are separated by an old channel cut of the river. The terrace is grass-covered, with the exception of scattered locust trees, and surface visibility is fair $(26-40 \%)$. There are numerous rodent mounds in the Speer loam sediments; these soils are formed in low alluvial terraces and are rarely flooded and are also well-drained. An apparent paleosol was detected across most of the site, with the top of the paleosol between $20-45 \mathrm{~cm}$ bs.

Shovel testing across the terrace indicate that the Eden site is about 18,750 square meters in size (4.7 acres). Five of six shovel tests contain prehistoric archeological materials, including moderate densities of lithic debris (15.20 pieces per positive shovel test) and ceramic sherds (2.50 sherds per positive shovel tests). These materials were recovered from 40-60 cm thick archeological deposits. The highest densities of lithic debris, and the only area with sherds in buried contexts, were found in ST 134 and ST 135 in the central part of the alluvial terrace.

A single flake tool of a dark gray novaculite was found on the surface at the Eden site. The tool has serrated, bilateral use wear and retouch (98.0 mm use wear length) on a large non-cortical hard hammer flake (see Figure 10d).

The two bifacial tool fragments (medial and lateral pieces) were recovered on the surface and in ST 139 (see Perttula and Nelson 2002: Table 6). Both were made from non-heat-treated novaculite - white or gray in color - and one of the tools had use-wear damage along one of the bifacial edges.

A total of 76 pieces of lithic debris were recovered in the shovel testing at the Eden site. Only 4\% are not novaculite - these being one piece of quartzite and two pieces of local yellowish-brown chert. A white novaculite is most abundant, comprising 55\% of the lithic debris sample, 
and other colors of novaculite represented are red, black, white-gray, and gray.

There are many cortical pieces in the collection (15.8\%), pointing to the importance of initial reduction and cortex removal knapping strategies, but many of the cortical pieces fall only in the medium size graded debris. As such, the lithic debris from the Eden sites also resembles the collections of lithic debris from the Fox (3PI147), Poppy Turner (3PI402), and J. Bean (3PI383) sites in the same stretch of the Little Missouri River (see Perttula and Nelson 2002: Table 9). The numbers of medium size graded pieces with cortex suggests that the raw material available for knapping may have been somewhat smaller in size (possibly from local gravel beds?) than was the case elsewhere at Lake Greeson, since in most other sites, the highest proportions of cortical flakes occur among the large $(2.54 \mathrm{~cm})$ size graded lithic debris. Overall, $80 \%$ of the lithic debris from the Eden site are medium to small in size.

Ten body and base sherds were found on the surface and in two shovel tests (ST 134 and ST 135). Two of the sherds (both grog-hematite-tempered) have broad parallel incised lines that are probably from Military Road Incised vessels (see Figure 11d), while the others are plain. Different tempers represented in the sherds include grog (40\%), grog-hematite (20\%), grit (30\%), and shell $(10 \%)$. The great majority of the sherds are from vessels fired and cooled in a reducing environment (70\%), comparable to the firing conditions in the Late Caddo ceramics at the Gentry site (3PI87), and the one shell-tempered sherd may represent a Late Caddo use of the Eden site. Looking at the ceramic assemblage as a whole, however, it is more likely that the prehistoric Caddo occupation at the Eden site took place during the earlier part of the Mid-Ouachita phase, when the use of shell-tempering was not yet common (see Early 2002a:11). The relatively thin $(6.50 \pm 1.47$ $\mathrm{mm}$ ) grit-tempered sherds may be from Mill Creek Plain vessels (see Early 1988).

Nine pieces of wood charcoal were found in ST 132 between $20-80 \mathrm{~cm}$ bs at the southern tip of the alluvial terrace. About $90 \%$ of the wood charcoal came from $40-80 \mathrm{~cm}$ bs, generally from the apparent paleosol.

\section{Fox (3PI147)}

The Fox site is a multicomponent prehistoric archeological site on an alluvial terrace (560 feet amsl) of the Little Missouri River, and just west of the Eden site. The terrace is currently grasscovered, with scattered locust trees, and surface visibility is fair $(26-50 \%)$ because of numerous rodent mounds in the deep Speer loam sediments. The site is estimated to cover 37,500 square meters (9.4 acres), based on the surface distribution of artifacts and the results of shovel testing across the landform.

All eight of the shovel tests contain prehistoric artifacts to depths between ca. $40-80 \mathrm{~cm}$ bs; the deepest archeological deposits occur in the vicinity of ST 244. The density of lithic debris is high (27.63 pieces per positive shovel test), and the highest densities are in ST 139, ST 140, ST 141, and ST 244 in the central and northern parts of the site. Bifacial tools, an arrow point, and a Gary dart point were recovered from the surface and in shovel testing. The recovery of fire-cracked rock between 20-60 cm bs in ST 244 suggests that burned rock features may be preserved here; the depth of the fire-cracked rock also suggests that such features may be from a prehistoric occupation that predates the Mid-Ouachita phase since all the ceramics in that shovel test were collected from $10-30 \mathrm{~cm}$ bs.

The Fox site also has a relatively high density (3.14 sherds per positive shovel test) of prehistoric Caddo ceramics, probably dating to the Mid-Ouachita phase (ca. A.D. 1400-1500). Seven of the eight shovel tests contain prehistoric ceramics between $0-60 \mathrm{~cm}$ bs, and 18 sherds were collected from the site surface. The highest densities of sherds are found in the northern part 
of the site in ST $142(n=5)$ and ST $244(n=4)$; burned clay was also found on the site.

OCR samples were taken at $10 \mathrm{~cm}$ intervals from ST 244 in the northern part of the alluvial terrace, beginning at $8-10 \mathrm{~cm}$ bs, and extending to $80 \mathrm{~cm}$ bs. These samples were obtained in order to obtain estimated dates on the age of the prehistoric Caddo occupation at the Fox site. The first six samples are in Zone 1 (a yellowish-brown sandy loam), containing prehistoric Caddo archeological materials with abundant lithic and ceramic artifacts, and the seventh and eighth samples came from Zone 2, a yellowish-brown sandy loam $(68-80 \mathrm{~cm}$ bs $)$. This zone contains a few pieces of temporally undiagnostic lithic debris.

The OCR dates from ST 244 are provided in Table 10. Three pedogenic markers were identified in the ST 244 column, one in the upper part of Zone $1(18-20 \mathrm{~cm} \mathrm{bs})$, a second in the lower part of Zone $1(38-40 \mathrm{~cm}$ bs), and the other at the top of Zone $2(68-70 \mathrm{~cm} \mathrm{bs})$. Caddo ceramics were found in ST 244 only between $0-30 \mathrm{~cm}$ bs. The uppermost pedogenic marker dates to A.D. 1410-1440, and indicates a period of pedogenic activity associated with the occupation of the Fox site in Mid-Ouachita phase times. The second pedogenic marker dates to A.D. 986-1042, and suggests a period of pedogenic activity in Early Caddo times. The lowermost pedogenic marker dates between A.D. 640-716. These dates suggest the initiation of an accumulation of alluvium at the Fox site during the $7^{\text {th }}$ and $8^{\text {th }}$ centuries, and these deeper deposits may also be associated with an earlier prehistoric use of the alluvial landform in Woodland period times.

Table 10. OCR Dates from the Fox Site (3PI147).

Provenience $\quad$ Pedogenic Marker $\quad$ ACT \# Calculated OCR Date (A.D.)

\begin{tabular}{|c|c|c|c|}
\hline $8-10 \mathrm{~cm}$ & & 5976 & A.D. $1562-158$ \\
\hline $18-20 \mathrm{~cm}$ & Yes & 5978 & A.D. 1410-144 \\
\hline $28-30 \mathrm{~cm}$ & - & 5979 & A.D. $1226-126$ \\
\hline $38-40 \mathrm{~cm}$ & Yes & 5980 & A.D. 986-1042 \\
\hline $48-50 \mathrm{~cm}$ & - & 5981 & A.D. $785-851$ \\
\hline $58-60 \mathrm{~cm}$ & - & 5977 & A.D. $823-887$ \\
\hline $68-70 \mathrm{~cm}$ & Yes & 5982 & A.D. 640-716 \\
\hline $78-80 \mathrm{~cm}$ & - & 5983 & A.D. $295-391$ \\
\hline
\end{tabular}

note: bolded entries represent dated pedogenic markers

A single Gary, var. LeFlore dart point was collected from the surface of the Fox site. This early Woodland or Fourche Maline Culture point had a rounded stem and a resharpened blade (see Figure 10j).

The lithic debris sample from the Fox site totals 221 pieces. More than $97 \%$ are novaculite, principally white $(48.9 \%)$, red $(20.8 \%)$, gray $(17.6 \%)$, and several other colors. The frequency of gray novaculite is higher here than at other Lake Greeson sites (see Perttula and Nelson 2002: Table 8), as is white-black, black, and brown novaculite. It seems likely that the composition of raw materials varied somewhat in different gravel beds along the Little Missouri River. The only other lithic raw materials in the lithic debris are Big Fork chert (1.3\%), other local chert (1.0\%), and quartzite $(0.5 \%)$.

The Fox site has a high percentage of cortical flakes $(11.3 \%)$ in the assemblage, with particularly high amounts proportionally among the $1.27,1.92$, and $2.54 \mathrm{~cm}$ size grades (see Perttula and Nelson 2002: Table 9) compared to the other Lake Greeson sites. Nevertheless, fully $73 \%$ of the lithic debris is small to medium in size grade - and the frequency of small $(0.64 \mathrm{~cm})$ lithic 
debris $(23.1 \%)$ is among the highest of any of the Lake Greeson sites (see Perttula and Nelson 2002: Table 9)_-suggesting an emphasis on both initial lithic reduction and final tool shaping/ resharpening as well as the use of smaller cobbles of stream-rolled lithic raw material, perhaps from a local gravel source.

As noted above, prehistoric Caddo ceramic sherds are relatively abundant at the Fox site in surface $(n=18)$ and shovel test $(n=20)$ contexts, but are not associated with the Gary dart point. Most of the sherds have been tempered with grog (52.6\%), grog-hematite (18.4\%), or grog-grit $(10.5 \%)$, and about $10 \%$ of the sherds have some combination of grog, grit, and bone. None of the other Lake Greeson Caddo sites have more than about 3\% bone-tempered sherds. A single sherd has shell temper, but six of the eight Lake Greeson sites with ceramics have shell-tempering (see Perttula and Nelson 2002: Table 10), although it is only abundant in the Late Caddo midden at the Gentry site (3PI87). The grog-tempered sherds are relatively thin (mean body wall thickness of $6.70 \mathrm{~mm}$ ), thus contributing to more efficient use of the vessels for cooking tasks, and the sherds are from generally well-fired and well-made vessels.

Like the Mid-Ouachita phase component at the Star of the East site (3PI138), a considerable number of sherds from this site are from vessels that were fired in an oxidizing environment (8\%), or were incompletely oxidized during firing (23\%). By way of comparison, none of the sherds at the Late Caddoan Gentry site were from vessels fired in an oxidizing environment, and only $7 \%$ were from incompletely oxidized vessels. The frequency of oxidized/incompletely oxidized sherds suggests that the vessels here were low-fired, and probably not for a long time, while the Late Caddo potters had changed their means of firing vessels, which were mostly shell-tempered, thus firing them longer and producing a stronger (i.e., more resistant to thermal shock), more durable, but ultimately a thinner cooking vessel.

Six of the body sherds are decorated. Four are body sherds from Military Road Incised vessels, with three having parallel to diagonal incised lines, and one having diagonal incised lines adjacent to a row of small circular punctations. One other body sherd has only a single broad incised line, and another (ST 142, 40-60 cm) has light parallel brushing marks on the lower vessel body; the latter is from a cooking jar. The combination of considerable use of grog temper, the virtual absence of shell-tempered vessels, the similarity in firing conditions between the Fox site and the Mid-Ouachita phase component at the Star of the East site (3PI138), and the prevalence of Military Road Incised vessels, all point to a prehistoric Caddo occupation during the earlier part of the Mid-Ouachita phase.

Two charred hickory nutshells and one piece of wood charcoal were found in ST 141, ST 142, and ST 244 in the central and northern part of the site. The wood charcoal came from 0-20 $\mathrm{cm} \mathrm{bs}$, and the nutshell pieces were found between $20-60 \mathrm{~cm}$ bs.

\section{J. Bean Site (3PI383)}

The J. Bean site was occupied during the Late Paleoindian, Late Archaic, and Late Prehistoric periods. The site is on an alluvial terrace (560 feet amsl) in a bend in the Little Missouri River; the terrace stands about 1-1.5 $\mathrm{m}$ above the floodplain. The landform is wooded with pines and hardwoods, and the understory is thick vines. Surface visibility is poor (0-25\%).

The floodplain to the north of the J. Bean site appears to have been mined for gravel in the past, but the mining has not disturbed the site itself. Several unimproved roads cross and/or border the site, and a small amount of prehistoric lithic debris was noted in the unimproved road along the northern site boundary. The shovel test investigations across the terrace suggest that the 
site is ca. 45,000 square meters in size (11.25 acres), but the site probably extends well to the east on to private property.

Thirteen shovel tests were excavated at the site, and each of them contained prehistoric lithic and/or ceramic artifacts between $20-60 \mathrm{~cm}$ bs. The density of lithic debris is 11.85 pieces per positive shovel test, and the highest densities are apparent along either the southwestern and northeastern parts of the terrace. The southwestern part of the landform also has the thickest or deepest archeological deposits $(60 \mathrm{~cm}$ in thickness). The chipped lithic tools and fire-cracked rocks were also found in the southwestern part of the site, and the differences in depths of arrow points and ceramics (0-40 $\mathrm{cm}$ bs) compared with the depths of a parallel-stemmed dart point $(40-56 \mathrm{~cm}$ bs) and a Dalton point (40-60 cm bs) suggests that the J. Bean site may contain stratified and/or older archeological deposits in this part of the landform. The recovery of fire-cracked rock in one shovel test in the southwestern part of the site may indicate that burned rock features are also preserved at the site; the depths of the fire-cracked rock $(0-40 \mathrm{~cm} \mathrm{bs})$ suggest they are associated with the Late Prehistoric Caddo occupation.

A single triangular Maud, var. Hopper arrow point came from ST $172(0-20 \mathrm{~cm})$. It has a deep basal concavity, and was made from a dark gray novaculite (see Figure 10b). A Maud, var. Hopper specimen was reported by Early (2000:Figure 43e) from the Winding Stair site (3MN496) in a context dating from ca. A.D. 1470-1500, the latter part of the Mid-Ouachita phase.

One of the two dart points from the site is a Dalton lanceolate from ST 175 made from a dark gray novaculite (see Figure 10f). It has a concave base, no ears, the broad blade has been resharpened or beveled, and the stem has been ground; the tip has also been broken from an impact fracture. Recent calibrated radiocarbon dates from the Big Eddy site in southwestern Missouri indicate that Dalton points likely date from ca. 10,500-10,000 years ago (Lopinot et al. 1998:199). The other dart point is a Marshall type - dating to the latter part of the Middle Archaic period according to Schambach (1998) — made from a white novaculite. It has a parallel stem, a flat base and short stem, and corner-notching of the blade; there are small barbs and the blade has been resharpened.

One bilateral flake tool, with steep and opposed retouch and use wear, was found in ST $171(0-20 \mathrm{~cm} \mathrm{bs})$. The flake was on a cortical flake of gray novaculite, and has a total use wear length of $61.0 \mathrm{~mm}$ (see Table 9).

The lithic debris sample $(\mathrm{n}=154)$ is comprised almost exclusively of novaculite $(96.2 \%)$. The remainder is Big Fork chert (2.6\%) and gray and brown cherts from local river gravels. White $(55.8 \%)$, gray $(11.0 \%)$, and red $(10.7 \%)$ colors are the most common colors among the novaculite, with much lesser amounts of white-gray $(7.1 \%)$, white-black $(3.2 \%)$, white-red $(1.3 \%)$, and yellow $(0.6 \%)$.

The J. Bean site has a high percentage of cortical flakes $(9.8 \%)$ in the assemblage, with particularly high amounts proportionally among the $0.64,1.27,1.92 \mathrm{~cm}$ size grades (see Perttula and Nelson 2002: Table 9) compared to all the other Lake Greeson sites. Notably, none of the large flakes $(2.54 \mathrm{~cm})$ have cortex. However, $85 \%$ of the lithic debris is small to medium in size grade - and the frequency of small $(0.64 \mathrm{~cm})$ lithic debris $(22.7 \%)$ is among the highest of any of the Lake Greeson sites - suggesting an emphasis on both initial lithic reduction to produce flakes (rather than bifaces) and final tool shaping/resharpening as well as the use of smaller cobbles of stream-rolled lithic raw material, perhaps from a local gravel source.

The J. Bean site has a few pieces of prehistoric Caddo pottery from ST 172 and ST 176. The sherds are either grog or shell-tempered, and are probably from a Mid-Ouachita phase occupation dating from ca. A.D. 1400-1500 (see Early 2002a). Two of the sherds are grog-tempered, and have broad parallel incised lines; one has triangular punctations between two parallel incised lines. Both 
sherds are probably from Military Road Incised vessels, one fired in a reducing environment and the other fired in an oxidizing environment. The third sherd is a plain shell-tempered body sherd. The small ceramic assemblage at the J. Bean site, which has both grog-and shell-tempered vessels, is consistent with an occupation during the middle parts of the Mid-Ouachita phase. By the latter part of the phase, shell-tempered pottery was much more common, and even more frequent in subsequent post-A.D. 1500 Caddo occupations (see Early 2002b:11).

Finally, four pieces of wood charcoal were also recovered from ST 172 and ST 175, primarily from $20-40 \mathrm{~cm}$ bs.

\section{Poppy Turner Site (3PI402)}

The Poppy Turner site is on an alluvial terrace (560 feet amsl) in the Little Missouri River valley. It is a short distance northeast of the Fox site, separated by an old channel of the river, and north of the White Oak Creek and Eden sites. All four sites are on similar landforms, with Speer loam sediments. These formed in loamy sediments in floodplain and low terrace landforms of the Little Missouri River.

The alluvial terrace is a grass-covered pasture, with fair surface visibility (40\%) because of the numerous rodent mounds exposed on the surface. The terrace has been previously cultivated, and a powerline crosses the site. Prehistoric lithic and ceramic artifacts are common in surface contexts, including several Gary dart points and 17 ceramic sherds. All nine shovel tests on the terrace contain prehistoric archeological deposits between $20-60 \mathrm{~cm}$ in thickness; the deepest archeological deposits were identified at the southern end of the alluvial terrace.

The Poppy Turner site has a high density of prehistoric lithic debris (27.89 pieces per positive shovel test), with the highest densities in the southern and central parts of the site. This area also has several chipped lithic tools, including a corner-notched arrow point and several bifacial tools between 0-40 cm bs. A number of prehistoric Caddo sherds were found in five shovel tests at the site, extending from north to south across the alluvial terrace and from 0-60 cm bs. ST 147 at the southern part of the site has the highest number of sherds $(n=10)$, and $80 \%$ of these were recovered between $0-40 \mathrm{~cm}$ bs.

Two arrow points were found in ST 147 and ST 149 in the southern and central parts of the site (see Table 7). Both-a Massard B and a Sequoyah-were made from a non-heat-treated white novaculite, have serrated blades, and expanding stems with corner notches (see Figure 10a, c). These forms are consistent with a Mid-Ouachita phase Caddo occupation as suggested by the decorated Caddo ceramics found on the surface and in shovel testing.

Four dart points were collected from the surface of the Poppy Turner site. Three are contracting stem Gary points, and one has a parallel stem and a concave base, and resembles a Bulverde point. The Gary points have rounded stems and are relatively thick, with broad stem widths. Two are Gary, var. Gary (ca. 2800-2100 B.P.) forms (one is made of a white chert and the second from a white novaculite), and the other is a Gary, var. LeFlore. These forms are slightly thinner and narrower than the older var. Gary, and probably date from ca. 400 B.C. to A.D. 200, in the Woodland period. The probable Bulverde point of gray novaculite has a parallel stem with a flat base, and the blade has been resharpened. Schambach (1998) considers Bulverde points to be Late Archaic forms made around 2000 B.C. He goes on to suggest that the Native Americans that made Bulverde points were part of a culture "with many regional and temporal phases that was very widespread in the rolling foothills and West Gulf Coastal Plain country of east Texas, south-central and southwest Arkansas, northwest Louisiana and, probably, in the Lower Mississippi Valley as well" (Schambach 1998:116). 
Three bifacial tool fragments were recovered in ST 147 and ST 150, as well as on the surface. All were made from a gray novaculite, and they each have retouching and use wear along the bifacial edges of the pieces (one medial piece and two tip/medial pieces). The novaculite had been heat-treated before the bifacial tool was manufactured.

The lithic debris from the Poppy Turner site $(\mathrm{n}=251)$ is dominated by novaculite $(96.8 \%)$, with small amounts of Big Fork chert $(2.4 \%)$, quartzite $(0.4 \%)$, and quartz $(0.1 \%)$. The white $(43.0 \%)$ and red $(26.7 \%)$ novaculite are the predominant colors, along with white-gray novaculite $(13.9 \%)$; this site has the highest proportions of white-gray novaculite of any of the Lake Greeson sites (see Perttula and Nelson 2002: Table 9). Other novaculite colors present in the lithic debris sample are white-black (1.6\%), yellow (1.2\%), and black (1.2\%).

The Poppy Turner site has a relatively high percentage of cortical flakes $(6.8 \%)$ in the assemblage, with particularly high amounts proportionally among the $0.64 \mathrm{~cm}$ size graded debris (3.7\%) compared to all the other Lake Greeson sites, where the mean percentage of cortical flakes in the $0.64 \mathrm{~cm}$ size class is $1.5 \%$. Also, few of the large flakes $(2.54 \mathrm{~cm})$ have cortex. However, $89 \%$ of the lithic debris is small to medium in size grade - and the frequency of medium-sized (1.27 $\mathrm{cm}$ size grade) and small size graded lithic debris $(67.8 \%$ and $21.5 \%$, respectively) is the highest of any of the Lake Greeson sites (see Perttula and Nelson 2002: Table 9). This points to an emphasis on both initial lithic reduction to produce flakes (rather than reduce large bifaces or cores) for tools and final tool shaping/resharpening, as well as the use of smaller cobbles of streamrolled lithic raw material.

The 29 prehistoric sherds from the surface and five shovel tests also indicate that the Poppy Turner site was occupied by the prehistoric Caddo, at least a millennia later than the Native American group that left the contracting stem dart points on the alluvial landform. At least $96 \%$ of the sherds are tempered with grog (see Perttula and Nelson 2002: Table 10), and only 3.4\% have shell-tempering (a plain body sherd). Some of the sherds also have grit or crushed hematite added as temper inclusions, and this was also noted in the larger Mid-Ouachita phase ceramic component at the Star of the East site. Unlike that site, however, only $25 \%$ of the sherds at the Poppy Turner site are from vessels fired in an oxidizing environment or incompletely oxidized during firing, compared to 45\% from Star of the East site (see Perttula and Nelson 2002: Table 11). The higher frequency of sherds from vessels fired in a reducing environment is more like that noted for the Late Caddo Gentry site, suggesting temporal changes in firing conditions or more diverse means of firing vessels during the Mid-Ouachita phase than was the case after ca. A.D. 1500.

Twelve of the sherds are decorated, including one with an interior/exterior red slip; tool punctated rows $(n=1)$; single incised lines, either straight or curvilinear $(n=4)$; fingernail punctated sherds ( $\mathrm{n}=2)$; and four Military Road Incised body sherds (see Figure 11e-f). The latter have parallel and broadly-spaced incised lines and two also have rows of tool or fingernail punctates below sets of parallel (horizontal?) or opposed incised lines on the vessel body. As with the Fox site, the combination of considerable use of grog temper, the virtual absence of shell-tempered vessels, and the prevalence of sherds from Military Road Incised vessels, all point to a prehistoric Caddo occupation during the earlier part of the Mid-Ouachita phase.

\section{Conclusions}

Prehistoric Caddo sites are apparently abundant throughout the wooded river valleys of the southern Ouachita Mountains in southwestern Arkansas. Although the sites discussed here have only been documented throughout archeological survey investigations (including intensive shovel testing), we have gathered some significant information on the overall character of the Caddo occupations at them, as well as the kinds of prehistoric ceramic artifacts and stone tools that were being made and used by the Caddo groups living in this part of the Ouachita Mountains between about 1000 and 400 years ago. 
Beginning in Late Holocene times, particularly after about 2000 years ago, the prehistoric populations in and around the Ouachita Mountains began to manipulate certain plants to increase their yield and predictability, including annuals that produced abundant seeds as well as mast crops. Sites occupied at this time were distributed differently across the landscape than those earlier sites of the more mobile hunter-gatherers as the economic focus of settlements had changed to take advantage of richer and wetter, as well as shaded, habitats near streams and amidst fertile lands where mast could be gathered and processed along with other resources. As they developed a more sedentary lifeway, this change is reflected in the character of the archeological sites themselves. That is, they manifest evidence for more intensive use, have some evidence of spatial differentiation across the land in the performance of economic tasks, and they may contain more abundant remains of plant and animal food processing, including fire-cracked rock used in hot rock cooking.

The Late Holocene sedentary Caddo communities had economies more focused on the cultivation of maize and other tropical and native cultigens, as well as a continued reliance on the bounty of the forested mountains and alluvial valleys. The Caddo groups probably lived in dispersed farmsteads and small communities, but were always to some extent linked by ties of kinship and ritual with larger communities of Caddo populations that served as centers of a rich religious and political life. These groups depended upon the availability of fertile and arable soils to raise their crops, and this is a natural resource in short supply throughout much of the Ouachita Mountains. Caddo farmsteads and small communities are present throughout this mountainous area, generally being found on flat ground near sources of fresh water, and the "extent and distribution of suitable soils in relatively flat terrain... would be one locational factor in the distribution of individual homesteads and the configuration of communities" (Early 2000:7). The major stream valleys were the nexus of Late Holocene Caddo groups, but important community centers like the Winding Stair site (3MN496) (Early 2000:126-128) can also be expected in favorable locations in the smaller and more rugged alluvial valleys within the Ouachita Mountains.

We hope that further archeological research will be carried out at the prehistoric Caddo sites mentioned in this article-as well as at others throughout the Ouachita Mountains in southwestern Arkansas - to better understand the nature of prehistoric Caddo adaptive lifeways in this rugged environment. We also hope that these Caddo sites, being on U.S. Army Corps of Engineers property, will be protected and preserved for the long-term by the federal government, and action should be taken now since they are threatened by continued shore erosion and site looting.

\section{Acknowledgments}

We very much appreciate the opportunity provided by the U.S. Army Corps of Engineers, Vicksburg District, to conduct the archeological surveys at DeGray Lake, Lake Ouachita, and Lake Greeson, and especially wish to thank Wayne Stogsdill. Meeks Etchieson of the U.S. Forest Service gave us the opportunity to examine the artifact collections from 3MN2185 as part of the Ice Storm project investigations. We would also like to thank Sandra Hannum for preparing the maps for this article.

\section{References Cited}

Brown, J. A.

1996 The Spiro Ceremonial Center: The Archaeology of Arkansas Valley Caddoan Culture in Eastern Oklahoma. 2 Vols. Memoirs No. 29. Museum of Anthropology, University of Michigan, Ann Arbor. 
Collins, M. B.

1998 Background to the Archeological Investigations. In Wilson-Leonard: An 11,000-year Archeological Record of Hunter-Gatherers in Central Texas, assembled by M. B, Collins, pp. 55-67. 5 Vols. Studies in Archeology 31, Texas Archeological Research Laboratory, The University of Texas at Austin, and Archeology Studies Program, Report 10, Texas Department of Transportation, Environmental Affairs Division, Austin.

Early, A. M.

1988 Standridge: Caddoan Settlement in a Mountain Environment. Research Series No. 29. Arkansas Archeological Survey, Fayetteville.

2002a The Mid-Ouachita Phase. Field Notes 305:10-13. Newsletter of the Arkansas Archeological Society.

2002b The Social Hill Phase. Field Notes 306:10-13. Newsletter of the Arkansas Archeological Society.

Early, A. M. (editor)

1993 Caddoan Saltmakers in the Ouachita Valley: The Hardman Site. Research Series No. 43. Arkansas Archeological Survey, Fayetteville.

2000 A Millennium of Human Occupation at Winding Stair in the Ouachita Mountains. Research Series 57. Arkansas Archeological Survey, Fayetteville.

Frink, D. S.

1992 The Chemical Variability of Carbonized Organic Matter through Time. Archaeology of Eastern North America 20:67-79.

1994 The Oxidizable Carbon Ratio (OCR): A Proposed Solution to some of the Problems Encountered with Radiocarbon Data. North American Archaeologist 15(1):17-29.

1995 Application of the Oxidizable Carbon Ratio Dating Procedure and its Implications for Pedogenic Research. In Pedological Perspectives in Archeological Research, pp. 95-106. SSSA Special Publication No. 44. Soil Science Society of America, Madison, Wisconsin.

1999 The Scientific Basis of Oxidizable Carbon Ratio (OCR) Dating. SAA Bulletin 17(5):3237.

Frink, D. S. and T. K. Perttula

2001 Analysis of the 39 Oxidizable Carbon Ratio Dates from Mound A, Mound B, and the Village Area at the Calvin Davis or Morse Mounds Site (41SY27). North American Archaeologist 22(2):143-160.

Guendling, R. L.

2000 Bug Spot Site. In A Millennium of Human Occupation at Winding Stair in the Ouachita Mountains, edited by A. M. Early, pp. 55-68. Research Series 57. Arkansas Archeological Survey, Fayetteville.

Heartfield, Price, and Greene, Inc.

1980 A Cultural Resource Survey of Selected Recreation Areas at Lake Greeson, Arkansas. Heartfield, Price, and Greene, Inc., Monroe. 
Lafferty, R. H., III, A. M. Early, M. C. Hill, M. C. Sierzchula, G. S. Powell, N. H. Lopinot, L. S. Cummings, S. L. Scott, S. K. Nash, and T. K. Perttula

2000 Data Recovery at the Helm Site, 3HS449, Hot Spring County, Arkansas. MCRA Report 2000-1. Mid-Continental Research Associates, Inc., Lowell, Arkansas.

Lopinot, N. H., J. H. Ray, and M. D. Conner (editors)

1998 The 1997 Excavations at the Big Eddy Site (23CE426) in Southwest Missouri. Special Publication No. 2. Center for Archeological Research, Southwest Missouri State University, Springfield.

Perttula, T. K. and B. Nelson

2000 Archeological Survey of 1608 Acres at DeGray Lake, Clark and Hot Spring Counties, Arkansas. 2 Vols. Report of Investigations No. 39. Archeological and Environmental Consultants, Austin.

2001 Archeological Survey of Four Tracts of Land at Lake Ouachita, Garland and Montgomery Counties, Arkansas. Report of Investigations No. 47. Archeological and Environmental Consultants, Austin.

2002 Archeological Survey of 721 Acres at Lake Greeson, Pike County, Arkansas. Report of Investigations No. 54. Archeological and Environmental Consultants, Austin.

Perttula, T. K. and N. G. Reese

2002 Findings of the Ice-Storm Project on Ouachita National Forest Lands in Southwest Arkansas. MS on file, Ouachita National Forest, Hot Springs, Arkansas.

Rice, P. M.

1996 Recent Ceramic Analysis: 1. Function, Style, and Origins. Journal of Archeological Research 4(2):133-163.

Schambach, F. F.

1982 An Outline of Fourche Maline Culture in Southwest Arkansas. In Arkansas Archeology in Review, edited by N. L. Trubowitz and M. D. Jeter, pp. 132-197. Research Series No. 15. Arkansas Archeological Survey, Fayetteville.

1998 Pre-Caddoan Cultures in the Trans-Mississippi South: A Beginning Sequence. Research Series 53. Arkansas Archeological Survey, Fayetteville.

Schambach, F. F., J. C. Weber, and A. M. Early

n.d. Typology and Nomenclature for South Arkansas Ceramics: The Descriptive Classification. MS in preparation, Arkansas Archeological Survey, Fayetteville.

Schiffer, M. B., J. M. Skibo, T. C. Boelke, M. A. Neupert, and M. Aronson

1994 New Perspectives on Experimental Archaeology: Surface Treatment and Thermal Response of the Clay Cooking Pot. American Antiquity 59(2):197-217.

Teltser, P. A.

1993 An Analytical Strategy for Studying Assemblage-Scale Ceramic Variation: A Case Study from Southeast Missouri. American Antiquity 58(3):530-543. 